\title{
Effects of Maternal Obesity on Fetal Programming: Molecular Approaches
}

\author{
Caterina Neri ${ }^{1}$ and Andrea G. Edlow ${ }^{2,3}$ \\ ${ }^{1}$ Department of Obstetrics and Gynecology, Università Cattolica del Sacro Cuore, Rome 00100, Italy \\ ${ }^{2}$ Division of Maternal-Fetal Medicine, Department of Obstetrics and Gynecology, Tufts Medical Center, \\ Boston, Massachusetts 02111 \\ ${ }^{3}$ Mother Infant Research Institute, Tufts Medical Center, Boston, Massachusetts 02111 \\ Correspondence: aedlow@tuftsmedicalcenter.org
}

Maternal obesity has become a worldwide epidemic. Obesity and a high-fat diet have been shown to have deleterious effects on fetal programming, predisposing offspring to adverse cardiometabolic and neurodevelopmental outcomes. Although large epidemiological studies have shown an association between maternal obesity and adverse outcomes for offspring, the underlying mechanisms remain unclear. Molecular approaches have played a key role in elucidating the mechanistic underpinnings of fetal malprogramming in the setting of maternal obesity. These approaches include, among others, characterization of epigenetic modifications, microRNA expression, the gut microbiome, the transcriptome, and evaluation of specific mRNA expression via quantitative reverse transcription polmerase chain reaction (RT-qPCR) in fetuses and offspring of obese females. This work will review the data from animal models and human fluids/cells regarding the effects of maternal obesity on fetal and offspring neurodevelopment and cardiometabolic outcomes, with a particular focus on molecular approaches.

$\mathrm{T}_{1}^{\mathrm{h}}$ he prevalence of obesity has doubled since 1980. The World Health Organization estimates that more than 1.4 billion people $(\sim 33 \%)$ around the world are currently obese (WHO 2013). By 2030, it is projected that up to $58 \%$ of the world's adult population ( 3.3 billion) will be overweight or obese (Kelly et al. 2008). In the United States, $>60 \%$ of reproductive-age women are overweight at conception and more than one-third are obese, with a $70 \%$ increase in prepregnancy obesity in recent decades (Catalano and Ehrenberg 2006; Kim et al. 2007; Flegal et al.
2012). This means that a majority of infants born in the United States and throughout the world will be exposed to an overweight or obese in utero environment and likely to maternal overnutrition or high-fat diet (HFD) during key periods of perinatal development. The maternal obesity epidemic coincides with an increased interest in the impact of the intrauterine environment on fetal growth and development (Gluckman et al. 2008).

Hale and Barker's original "thrifty phenotype" hypothesis was based on the observation

Editors: Diana W. Bianchi and Errol R. Norwitz

Additional Perspectives on Molecular Approaches to Reproductive and Newborn Medicine available

at www.perspectivesinmedicine.org

Copyright (C) 2016 Cold Spring Harbor Laboratory Press; all rights reserved; doi: 10.1101/cshperspect.a026591

Cite this article as Cold Spring Harb Perspect Med 2016;6:a026591 
that individuals born at low-birth weight had an increased risk of cardiometabolic disease as adults (Hales and Barker 1992; Barker et al. 1993; Barker 1995). Historically, the developmental origins of health and disease (DOHaD) hypothesis have focused on the effects of maternal malnutrition and in utero nutritional deficiencies. Although maternal undernutrition remains a problem in many parts of the world, maternal overnutrition now poses a major public health challenge in both the developed and the developing world (Jehn and Brewis 2009). The increasing global burden of obesity creates a new set of concerns for the developing fetus. Maternal obesity has been associated with both intrauterine growth restriction and large-for-gestational age fetuses (Catalano et al. 2003; Nohr et al. 2007), and is contributing to the epidemic of childhood obesity and metabolic disorders (Armitage et al. 2008; Heerwagen et al. 2010). The fetal systems that appear most vulnerable to harmful programming are the central nervous system and the cardiometabolic system (a phenomenon referred to as "metabolic imprinting”) (Sullivan et al. 2011).

Epidemiologic data in humans show that offspring of obese parents are significantly more likely to be obese themselves and to have hypertension, type 2 diabetes, and metabolic syndrome (Petitt et al. 1985; Gillman et al. 2003; Boney et al. 2005; Oken et al. 2008; Reynolds et al. 2010). Although paternal obesity may contribute to deleterious fetal programming, an obesogenic in utero environment seems to be the most impactful, with maternal body mass index (BMI) being more significantly associated with offspring risk than paternal BMI (Lawlor et al. 2007). Recent evidence also indicates that maternal obesity is associated with adverse neurodevelopmental outcomes in children, including lower overall cognitive capabilities (Van Lieshout et al. 2011; Tanda et al. 2012); increased incidence of autism spectrum disorders and developmental delay (Hinkle et al. 2012; Krakowiak et al. 2012); increased incidence of attention deficit hyperactivity disorder (ADHD), anxiety, and other psychiatric disorders (Rodriguez et al. 2008); and increased incidence of cerebral palsy (Ahlin et al. 2013; Crisham Janik et al. 2013; Mehta et al. 2014; Pan et al. 2014). Although such studies can show an association between maternal obesity and these adverse outcomes, they cannot prove causality and do not provide information about the underlying mechanisms. Animal models and molecular approaches have played a key role in elucidating the molecular underpinnings of fetal malprogramming in the setting of maternal obesity. Such an understanding is crucial to designing and implementing interventions that can halt the intergenerational propagation of maternal obesity-associated neurodevelopmental morbidity.

In this work, we will review definitions of maternal obesity, followed by an overview of molecular techniques used in the study of maternal obesity and fetal programming. The cardiometabolic and neurodevelopmental programming aspects of maternal obesity will then be reviewed, including mechanistic data from animal models and human fluids/cells, again with a focus on how molecular techniques have elucidated mechanisms underlying fetal and offspring risk.

\section{DEFINITIONS OF MATERNAL OBESITY}

Most investigators use a definition of maternal obesity based on prepregnancy BMI (i.e., a BMI $\geq 30 \mathrm{~kg} / \mathrm{m}^{2}$ ). This measure has limitations, however. The most complete picture of maternal obesity and the obesogenic perinatal environment is provided by collecting data on prepregnancy BMI, pregnancy weight gain, and postpartum weight retention or loss. Additionally, traditional measures such as BMI or absolute pound or kilogram weight do not quantify the amount of body fat versus lean body mass, nor do they identify the areas of fat deposition, both of which may be relevant to the pathogenesis of conditions for mothers and offspring (Dulloo et al.2010). Central adiposity has been identified as particularly hazardous to adult health, but it remains unclear what fat deposition pattern during pregnancy might have the greatest impact on fetal development and child health outcomes (Mehta et al. 2014). Studies that use not only maternal BMI, but also some measure of maternal fat versus lean body mass and location 
of fat deposition would provide the opportunity to investigate some of these unanswered questions. In addition to defining the optimal measure of obesity, another conundrum is the issue of whether obesity itself causes adverse outcomes in offspring or is a marker for other factors/comorbidities which themselves are the causal entities.

\section{MOLECULAR APPROACHES USED IN THE STUDY OF MATERNAL OBESITY}

\section{Examination of Epigenetic Modifications}

One of the underlying mechanisms by which the in utero environment shapes the organism is through epigenetic modifications, which involve persistent and heritable modification of the genome without changes in the DNA sequence itself. Although genome-wide association studies have identified many loci associated with obesity, these loci are thought to contribute $<2 \%$ to the variation between BMI and weight between individuals (Loos 2009). This suggests that epigenetic phenomena rather than changes in the DNA sequence itself are most likely mediating some of the programming effects on offspring. Epigenetic modifications may involve DNA methylation; posttranslational histone modifications resulting in the stable alteration of chromatin structure (acetylation, methylation, ubiquitylation, and sumoylation); and microRNA variation. The effect of epigenetic variation on gene activation and inactivation is increasingly understood to have a profound effect on one's lifetime risk of obesity, metabolic and cardiovascular disorders, and neurological diseases. Exposure during the early stages of life to an obesogenic in utero environment has been shown to cause epigenetic modifications in the offspring, which may increase susceptibility to diseases such as type 2 diabetes, hypertension, obesity, and metabolic syndrome later in life (Ganu et al. 2012; Ross and Desai 2013).

\section{DNA Methylation}

DNA methylation patterns are established during embryogenesis, fetal development, and early postnatal life. They are important for promoting the silencing of specific gene regions, such as imprinted genes and repetitive nucleic acid sequences. Early embryonic DNA is hypomethylated. Organogenesis and tissue differentiation are associated with progressive increases in DNA methylation in response to environmental signals. Increased methylation is associated with transcriptional silencing. Anomalous DNA methylation may be associated with inappropriate gene silencing. Intrauterine conditions, such as growth and nutrient restriction, can epigenetically modify gene expression by altering the methylation level of DNA in gene promoter regions (Lillycrop et al. 2005; Burdge et al. 2007; Turner et al. 2010; van Straten et al. 2010). Less is known regarding alternative DNA methylation in the case of maternal overnutrition (Heerwagen et al. 2010).

Investigators have used a variety of molecular techniques to characterize methylation patterns and to provide quantitative DNA methylation measurements. Characterization of DNA methylation is typically followed by validation of downstream targets using quantitative reverse-transcription polymerase chain reaction (RT-qPCR amplification). Bioinformatics resources have also been used to determine potentially altered pathways and functions resulting from differential DNA methylation. Differential DNA methylation in the setting of maternal obesity has been examined in a variety of animal and human tissues (Vucetic et al. 2010; Borengasser et al. 2013; Guénard et al. 2013). Global genome-wide DNA methylation has been assessed in offspring brains of obese female mice using commercially available colorimetric kits followed by immunoprecipitation of methylated DNA via antibody against 5-methylcytosine (5mC, also called the MeDIP assay) (Vucetic et al. 2010). This study found global and genespecific promoter DNA hypomethylation in offspring brains. The hypomethylated genes included those involved in dopamine reuptake and opioid binding, both of which might predispose to reward-based eating and higher consumption of palatable and energy-dense food (Vucetic et al. 2010; Vucetic and Reyes 2010). In a rodent model of a maternal HFD, differen- 
tial methylation levels in white adipose tissue of offspring were quantified using reduced representation bisulfite sequencing (RBBS) (Borengasser et al. 2013). RRBS is accomplished by digesting genomic DNA with the restriction endonuclease MspI (methylation-insensitive restriction enzyme), followed by end repair, A-tailing, adapter ligation, bisulfite conversion, sequencing, and digital alignment. This permits digital quantification of $\mathrm{CpG}$ methylation on a genomic scale. RBBS has greater resolution compared with MeDIP, is more efficient in analyzing CpG-poor regions of the genome, and is not subject to cross-reactivity of the $5^{\prime} \mathrm{mC}$ antibodies used in the MeDIP procedure. A study in siblings born to obese mothers before and after gastric bypass surgery used human methylation bead chips that contain probes to detect a wide variety of known DNA methylation sites. Although some DNA methylation chips use MeDIP technology, others - like the chip used in this experiment-use bisulfite-converted genomic DNA and provide single-nucleotide resolution (Guénard et al. 2013).

\section{Histone Code Variations}

Differential packaging of chromatin into open (euchromatic) or closed (heterochromatic) states around histones is another important mechanism of gene expression and silencing. Posttranslational modification of histone tail residues, including acetylation, methylation, phosphorylation, ubiquitination, and sumoylation, has the potential to change the way histones interact with DNA (Heerwagen et al. 2010). A variety of molecular techniques have been used to study histone modifications in the setting of maternal obesity. The most commonly used is chromatin immunoprecipitation (ChIP) (Aagaard-Tillery et al. 2008; Shankar et al. 2010; Suter et al. 2011; Borengasser et al. 2014). The ChIP assay assesses the epigenetic status of histones at a given locus, and RT-qPCR amplification can then be used to measure the transcription level of the corresponding gene(s) of interest (Aagaard-Tillery et al. 2008; Suter et al. 2011; Borengasser et al. 2014). Histone modifications on different promoter regions of target genes have also been studied by using Western blotting with specific antibodies (Aagaard-Tillery et al. 2008).

Experiments in animal models have implicated histone modification as an epigenetic mechanism by which maternal obesity could affect developmental outcomes in their offspring. In Japanese macaques, in utero exposure to maternal HFD resulted in site-specific fetal histone code variation leading to alterations in gene expression (Aagaard-Tillery et al. 2008). The sitespecific modifications of the histone code led to reprogrammed expression of fetal genes involved in circadian rhythm regulation, feeding behavior, and glucose and lipid homeostasis. This pattern of altered gene expression was hypothesized to favor an obese postnatal phenotype in an anticipatory fashion (Aagaard-Tillery et al. 2008). Histone modification was subsequently showed to disrupt the expression of hepatic genes implicated in the maintenance of circadian rhythms and metabolic homeostasis in Japanese macaque and rat models (Suter et al. 2011; Borengasser et al. 2014).

\section{MicroRNA Variations}

MicroRNAs (miRNAs) are a third epigenetic or peritranscriptional mechanism by which maternal obesity and diet can affect long-term morbidity in offspring. miRNAs are small ( $\sim 21 \mathrm{nu}-$ cleotide) noncoding RNAs that regulate gene function mainly through degradation of mRNAs or via inhibition of protein translation (Zamore and Haley 2005). miRNAs are involved in the regulation of key biological processes, including organismal development, differentiation, cell proliferation, cell cycle regulation, and energy metabolism (Wienholds and Plasterk 2005; Boehm and Slack 2006; Gauthier and Wollheim 2006; Oakley and Van Zant 2007). It has been estimated that $\sim 30 \%$ of all protein-coding genes are regulated by miRNAs (Lewis et al. 2003). In animal models of maternal obesity, miRNAs have been shown to be differentially regulated in the offspring in multiple tissues, including liver, heart, and skeletal muscle (Zhang et al. 2009; Maloyan et al. 2013; Yan et al. 2013; Benatti et al. 2014). miRNA microarrays have been the 
Maternal Obesity and Fetal Programming

most commonly used technique to examine global miRNA expression (Zhang et al. 2009; Maloyan et al. 2013; Yan et al. 2013), with differentially regulated miRNAs often validated using real time RT-PCR (Zhang et al. 2009; Maloyan et al. 2013; Yan et al. 2013; Benatti et al. 2014). miRNA targets have been identified using prediction algorithms such as TargetScan (Lewis et al. 2003), Miranda (John et al. 2004), and PicTar (Krek et al. 2005). miRNA sequencing has been performed on hearts of fetal baboons of HFD-fed mothers (Maloyan et al. 2013). Commercially available bioinformatics resources were then used to determine specific pathways and biological functions impacted by the differential miRNA expression. Downstream mRNA and protein targets from miRNAs known to be tissue specific can be quantified by RT-qPCR (Maloyan et al. 2013) and via immunoblotting with specific antibodies (Maloyan et al. 2013; Benatti et al. 2014).

Changes in skeletal muscle miRNAs involved in intramuscular adipogenesis were noted in fetuses of obese ewes (Yan et al. 2013). In a mouse model of maternal HFD exposure, global miRNA profiling of pup livers showed an altered miRNA profile in offspring of females fed a HFD with reduced expression of miRNAs implicated in developmental timing/early fetal growth, lipid metabolism, and regulation of the gene Insulin-like Growth Factor 2 (Igf2) (Zhang et al. 2009). Similar findings were observed in murine model of maternal HFD exposure, which showed differential expression of offspring hepatic miRNAs involved in lipogenic gene activation and fatty acid oxidation (Benatti et al. 2014). Alterations in miRNA expression were also found in fetal hearts of obese baboons (Maloyan et al. 2013). Expression of the miRNAs that was affected by maternal HFD were similar to those shown to be changed in adult cardiac diseases such cardiac hypertrophy, heart failure, and myocardial infarction. The investigators concluded that epigenetic modifications in the form of differential miRNA regulation may represent one of the mechanisms by which maternal obesity results in an increased risk of cardiovascular disease in offspring (Maloyan et al. 2013).
RNA Studies: Transcriptomics, RT-qPCR, and RNA Sequencing

One step downstream from epigenetic modifications is the examination of RNA via transcriptomics, RT-qPCR, or RNA sequencing (RNA-Seq). RNA can be extracted from fluids and tissues of interest to investigate the effects of maternal obesity on fetal gene expression. Avariety of fetal and offspring transcriptomes have been studied to help elucidate programming effects of maternal obesity, including the amniotic fluid (Edlow et al. 2014), umbilical cord (Thakali et al. 2014), liver (Shankar et al. 2010; Mischke et al. 2013), brain (Stachowiak et al. 2013a), and white adipose tissue transcriptomes (Borengasser et al. 2013). Transcriptomic analysis has even been performed on the obese maternal uterus and on the blastocyst in the setting of maternal obesity (Shankar et al. 2011).

Transcriptomic analysis can provide realtime information about fetal disease, physiology, and functional development of fetal tissues (Edlow and Bianchi 2012). Whole-genome microarray has been the most commonly used technique to examine the global RNA expression profile. Separate arrays exist for genomes from humans (Hui et al. 2013; Edlow et al. 2014), mice (Mischke et al. 2013), and rats (Shankar et al. 2011; Borengasser et al. 2013). Functional analysis of the fetal transcriptome via bioinformatics resources such as gene set enrichment analysis (GSEA), database for annotation, visualization and integrated discovery (DAVID), and ingenuity pathways analysis (IPA), and others can highlight particular pathways, biological functions, or physiological systems that are dysregulated in a condition of interest, such as maternal obesity. Transcriptomics have largely been used as hypothesis-generating tools in this regard, and further investigation of results has often been undertaken via targeted RT-qPCR and animal models.

Pregestational maternal obesity has been shown to have effects on the fetus as early as implantation. Transcriptomic profiling of the blastocyst and maternal uterus in a rat model of preconceptional obesity showed proinflammatory changes in the maternal uterus and the 
blastocyst itself, as well as gene expression changes consistent with lipotoxicity (Shankar et al. 2011). Transcriptomic profiling of offspring white adipose tissue in a rat model of maternal obesity showed significant changes in gene expression in lipogenic pathways, suggesting increased propensity for adipogenesis in offspring (Borengasser et al. 2013). Transcriptomic analysis of human amniotic fluid in the second trimester suggested a proestrogenic, proinflammatory milieu for the developing fetus, with up-regulation of antiapoptotic genes and genes implicated in response to oxidative stress (Edlow et al. 2014). Transcriptomic analysis has also been used to evaluate the effect of maternal obesity on fetal brain (Stachowiak et al. 2013a) and offspring liver development (Mischke et al. 2013), with both organs demonstrating significant changes in gene expression in fetal and pup mice exposed to an obesogenic intrauterine environment.

RNA-Seq is a newer technique used to survey global gene expression. RNA-Seq provides improved resolution over microarrays, which require knowledge of an organism's genome and are typically not designed to detect rare allelic variants. RNA-Seq allows examination of alternatively spliced gene transcripts and posttranscriptional modification; determination of exon/intron boundaries; and characterization of a wide variety of RNA populations outside of mRNA (such as microRNA, transcript RNA, and long noncoding RNAs, among others). RNA-Seq has been used to examine skeletal muscle (soleus) transcriptional profiles of adult male offspring exposed to a HFD in utero. GSEA was used to identify dysregulated biological functions based on the RNA-Seq signatures of differential expression. The offspring soleus transcriptome showed evidence of reprogramming of skeletal muscle by maternal exposure to a $\mathrm{HFD}$, with increased muscle cytokine activation, inflammation, and mitochondrial dysfunction compared with controls (Latouche et al. 2014).

\section{Maternal Obesity and the Gut Microbiome}

Commensal gut microbiota is essential for metabolizing polysaccharides, producing key nu- trients, and protecting against pathogenic bacteria in the mammalian gut (Chow et al. 2010; Gohir et al. 2014). The gut microbiome functions as an integral part of the gut barrier and plays an important role in the immune system by controlling antigen exposure to host tissues (Luoto et al. 2013). Emerging evidence suggests that the bacterial composition of the gut microbiome modulates weight gain, alters metabolism, and contributes to the inflammatory status that drives obesity and chronic diseases (Ley et al. 2005; Turnbaugh et al. 2006; Santacruz et al. 2010; Harris et al. 2012). Alterations of commensal flora in a variety of pathological conditions have been referred to as "gut dysbiosis" (Gohir et al. 2014). Putative mechanisms by which gut microbiota could impact obesity center around the concept that specific microbes have the ability to induce excessive energy extraction and storage from ingested nutrients (Turnbaugh et al. 2006; Harris et al. 2012; Gohir et al. 2014). Gut microbiota are known to affect lipid metabolism (Harris et al. 2012) and host immunity (Myles et al. 2013), and thus may contribute to aberrant chronic low-grade inflammation in conditions such as obesity (Gohir et al. 2014). RT-qPCR and shotgun sequencing of the $16 \mathrm{~S}$ rRNA/rDNA gene sequence, and fluorescent in situ hybridization coupled with flow cytometry have been used to characterize the gut microbiome in human and animal models of obesity (discussed below) (Ley et al. 2005; Turnbaugh et al. 2006; Collado et al. 2008; Turnbaugh and Gordon 2009; Ma et al. 2014).

\section{Animal Models: Mechanistic Insights}

Animal models have advanced our understanding of the gut microbiome and its relationship to obesity and fetal programming. Shotgun sequencing of the gut microbiome of obese mice showed enrichment in genes coding for enzymes involved in energy extraction (Turnbaugh et al. 2006). These data are consistent with the idea that certain bacterial populations allow obese individuals to harvest more energy from a given amount of nutrient intake. Colonizing germ-free mice with microbiota from genetically and diet-induced obese mice resulted 
in increased body fat compared with germ-free mice colonized with microbiota from lean mice (Turnbaugh et al. 2006). Genetically obese ob/ob mice show shifts in the proportion of the two most abundant phyla in the mammalian gut, Firmicutes and Bacterioides, compared with lean control mice (Ley et al. 2005). Multiple studies have suggested that these two bacterial populations are particularly responsive to dietary changes in fat and carbohydrate content, and to weight gain or loss (Ley et al. 2006; Turnbaugh and Gordon 2009).

Several mechanisms have been proposed by which maternal obesity might impact neonatal microbiota composition and subsequently inform the risk of offspring obesity and metabolic dysregulation. The effects of maternal dietary composition and nutritional status may be transferred to the fetus via the placenta and to the infant via lactation. Dysbiosis is thought to promote intestinal monosaccharide absorption and energy extraction from carbohydrates, resulting in short-chain fatty acid production and hepatic lipogenesis. These undesirable metabolic changes could occur in both the obese mother and the developing fetus or neonate. Given that rapid weight gain in the first six months of life is associated with an increased risk of childhood obesity, harmful gestational "programming" of gut microbiota could have permanent effects on the offspring (Collado et al. 2010; Luoto et al. 2013).

Modifications in the gut microbiome of obese mothers have been well documented (Gohir et al. 2014). In a macaque model of maternal HFD, the intestinal microbiome of both mothers and offspring was altered (Ma et al. 2014). Gestational exposure to HFD resulted in gut dysbiosis in the juvenile primates that persisted despite a control diet postweaning. These changes in the juvenile gut microbiome were associated with dysregulation of pathways involved in amino acid, carbohydrate, and lipid metabolism (Ma et al. 2014). In both rodent and swine models, manipulation of maternal microbiota either through antibiotics or probiotics was shown to impact the structural and functional development of the gut in their offspring, suggesting that the maternal microbiome and factors im- pacting it have a significant impact on neonatal gut flora (Fak et al. 2008; Arnal et al. 2014). A murine model of parental HFD consumption found that offspring of Western diet breeders had a significantly increased Firmicutes-to-Bacterioides ratio compared with control offspring, and showed heightened colonic inflammatory responses and dysregulated autoimmunity and allergic sensitization. This study did not separate the effects of paternal and maternal diet, but concluded that parental HFD leaves a "lard legacy" that can impact offspring immunity (Myles et al. 2013).

\section{Human Studies: Mechanistic Insights}

Similar deleterious changes in the maternal and infant microbiome have also been noted in the setting of human maternal obesity. Obese or overweight pregnant women and those with excessive gestational weight gain (GWG) were shown to have a more proinflammatory gut microbiome than their lean counterparts (Collado et al. 2008). A follow-up study of infants of these same women showed that infant gut microbiota at one and six months were influenced by maternal prepregnancy BMI and GWG, with infants of obese and high GWG women demonstrating lower concentrations of protective bacteria, higher concentrations of proinflammatory bacteria, and alterations in the Bacterioides, Clostridium, and Staphylococcus profiles that could predispose offspring to enhanced energy storage, obesity, and decreased control of chronic low-grade systemic inflammation (Collado et al. 2010). The potentially harmful effects of maternal gut dysbiosis in the setting of maternal obesity may be amenable to therapeutic intervention. Oral administration of probiotic bacteria to pregnant women was shown to result in colonization of the infant gut lasting from six to 24 months postpartum (Schultz et al. 2004).

Further mechanistic studies, especially in humans, are needed to better understand how gut microbiota interact with the host immune response in the context of obesity. Pregnancy and early infancy appear to be the key stages for targeted interventions to reduce the risk of 
obesity metabolic syndrome and chronic disease in future generations.

\section{MATERNAL OBESITY AND OFFSPRING METABOLIC PROGRAMMING}

\section{Data from Epidemiological Studies}

Associations between maternal obesity and offspring risk of early-onset obesity and metabolic syndrome have been repeatedly shown in large epidemiological studies (Boney et al. 2005; Hochner et al. 2012; Sridhar et al. 2014). In fact, all-cause mortality has been shown to be increased in offspring of obese women compared with those with a normal BMI, even after adjusting for confounding variables (Reynolds et al. 2013). Both prepregnancy obesity and excess GWG are associated with large-for-gestationalage (LGA) or macrosomic newborns (Boney et al. 2005; Oken et al. 2008). LGA newborns have increased adipose tissue mass and are at increased risk of obesity and diabetes in adulthood (Armitage et al. 2008; Schellong et al. 2012; Sparano et al. 2013). Although epidemiological studies can show an association between maternal obesity and offspring cardiometabolic morbidity, such studies cannot establish causality nor can they elucidate mechanism. Animal models and the use of molecular techniques to analyze animal and human samples have provided more insight into the possible underlying molecular mechanisms.

\section{Animal Models: Mechanistic Insights}

Animal models of maternal obesity and its exposure to a high-fat or Western diet are numerous and are the subject of several recent dedicated reviews (Nathanielsz et al. 2007; Alfaradhi and Ozanne 2011; Li et al. 2011; Williams et al. 2014). Rodent, sheep, swine, and nonhuman primate models have all been used to pinpoint specific mechanisms involved in the fetal programming effects of maternal obesity (Fig. 1). These effects have been examined in a variety of fetal and offspring organs, including liver, bone, skeletal muscle, adipose tissue, pancreas, thyroid, and heart (Williams et al. 2014). Studies on animal models have reported insulin and leptin resistance (Morris and Chen 2009), hypertension (Elahi et al. 2009), dyslipidemia (Elahi et al. 2009), hepatic inflammation and steatosis (Howie et al. 2009; Li et al. 2013), hyperphagia (Samuelsson et al. 2008), and obesity (Li et al. 2013) in offspring. These effects do not appear to be reversible with postnatal diet alterations (Howie et al. 2009), but switching obese dams to a low-fat diet for a subsequent pregnancy has been shown to ameliorate the unfavorable metabolic profile of offspring in C57BL/6 mice (Krasnow et al. 2011).

Molecular techniques, including transcriptomic analysis of RNA extracted from fetal and offspring organs such as liver, adipose tissue, heart, pancreas, and brain; quantification of DNA methylation via bead chips or RBBS; chromatin immunoprecipitation assays to evaluate histone modification; miRNA profiling and RTqPCR have provided significant insight into the mechanisms underlying fetal programming in maternal obesity. Insights from these molecular investigations suggest that the liver is a major target for metabolic programming during fetal development. Investigators have discovered increased expression of hepatic lipogenic genes in fetuses and offspring of females on a HFD (Bruce et al. 2009; Hartil et al. 2009; Gregorio et al. 2010); reduced mitochondrial function, dysregulation of inflammatory gene expression, and increased expression of genes involved in glycolysis, gluconeogenesis, and oxidative stress in the liver of offspring exposed to a HFD in utero (Bruce et al. 2009; Vuguin et al. 2013); and epigenetic changes in offspring liver, including histone modification and altered $\mathrm{CpG}$ methylation patterns (Aagaard-Tillery et al. 2008; Strakovsky et al. 2011; Hoile et al. 2013).

The effects of maternal obesity and HFD on fetal programming are not limited to the fetal liver. There is evidence of increased expression of glucose and amino acid transporters in the placentas of dams on a HFD (Jones et al. 2009), dysregulation of pancreatic beta cell gene expression predisposing offspring to premature beta cell failure (Cerf et al. 2005, 2009; Williams et al. 2014); insulin resistance and altered expression of insulin signaling proteins in skeletal muscle (Buckley et al. 2005), alterations in bone 


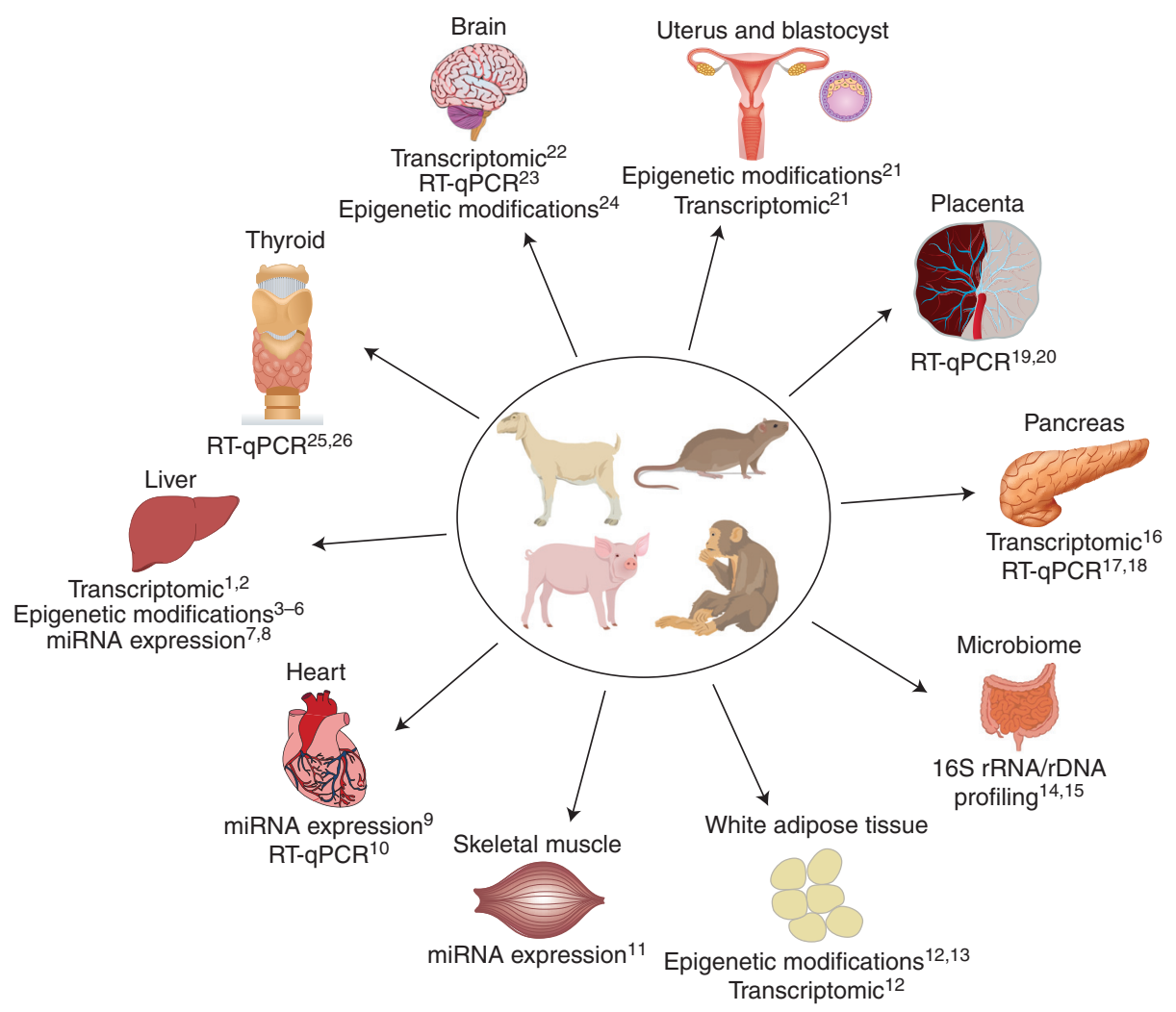

Figure 1. Molecular techniques provide insight into fetal organ developmental programming in animal models of maternal obesity. RT-qPCR, quantitative reverse transcription PCR. (Data for the figure from the following references: ${ }^{1}$ Mischke et al. 2013; ${ }^{2}$ Bruce et al. 2009; ${ }^{3}$ Vucetic et al. 2010; ${ }^{4}$ Aagaard-Tillery et al. $2008 ;{ }^{5}$ Suter et al. 2011; ${ }^{6}$ Borengasser et al. 2014; ${ }^{7}$ Zhang et al. 2009; ${ }^{8}$ Benatti et al. 2014; ${ }^{9}$ Maloyan et al. 2013; ${ }^{10}$ Elahi and Matata 2014; ${ }^{11}$ Yan et al. 2013; ${ }^{12}$ Borengasser et al. 2013; ${ }^{13}$ Masuyama and Hiramatsu 2012; ${ }^{14}$ Ma et al. $2014 ;{ }^{15}$ Myles et al. 2013; ${ }^{16} \mathrm{Ng}$ et al. 2014; ${ }^{17} \mathrm{Cerf}$ et al. 2006; ${ }^{18} \mathrm{Cerf}$ et al. 2009; ${ }^{19}$ Jones et al. 2009; ${ }^{20} \mathrm{Zhu}$ et al. 2010; ${ }^{21}$ Shankar et al. 2011; ${ }^{22}$ Stachowiak et al. 2013b; ${ }^{23}$ Moraes et al. 2009; ${ }^{24}$ Vucetic et al. $2010 ;{ }^{25}$ Franco et al. 2012; ${ }^{26}$ Suter et al. 2012.)

marrow adiposity and trabecular structure (Lanham et al. 2010); and epigenetic changes in adipocytokine gene expression (Masuyama and Hiramatsu 2012).

\section{Human Studies: Mechanistic Insights}

Human studies of the programming effects of maternal obesity have also elucidated underlying mechanisms, largely through the use of molecular techniques (Fig. 2). Several studies have shown a lower prevalence of obesity and improved metabolic parameters (greater insulin sensitivity, less adiposity, hypertension, and dyslipidemia) in children born after maternal gastric bypass surgery compared with siblings born before maternal bariatric surgery (Kral et al.
2006; Smith et al. 2009; Barisione et al. 2012). Findings of these well-designed sibling studies suggest that such improvements in offspring obesity and metabolic profile may be because of a change in the intrauterine environment. Investigators subsequently compared DNA methylation and global gene expression of children born to the same mothers before and after maternal bariatric surgery (Guénard et al. 2013). Using BeadChip arrays they identified $\sim 5700$ differentially methylated genes in siblings born before versus after maternal bariatric surgery. Functional analysis showed that these genes were principally involved in glycemic control, immune and inflammatory response, and cardiovascular functions. 
C. Neri and A.G. Edlow

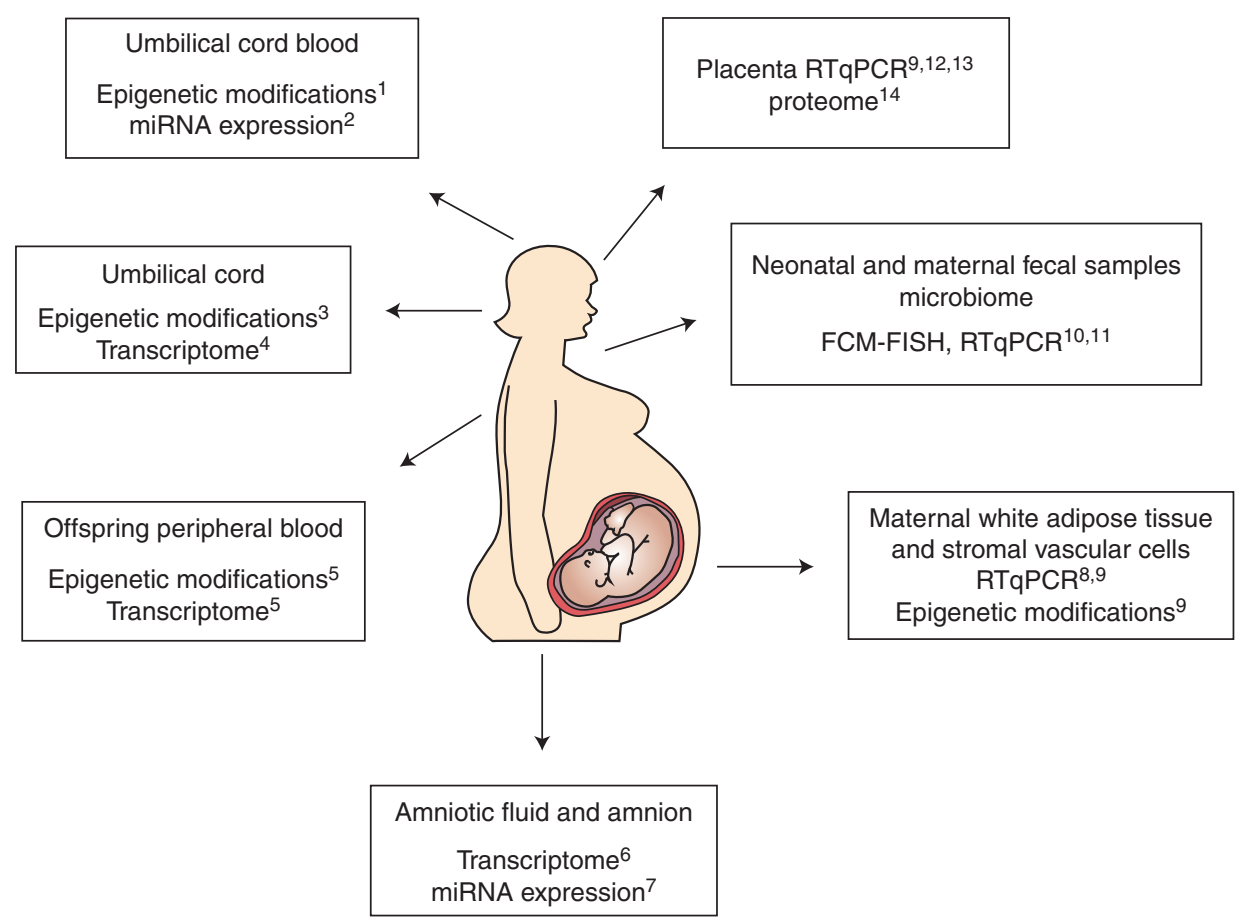

Figure 2. Molecular techniques provide insight into fetal developmental programming using human fluids and tissues. FCM-FISH, fluorescent in situ hybridization coupled with flow cytometry; RT-qPCR, quantitative reverse transcription PCR. (Data for the figure from the following references: ${ }^{1}$ Soubry et al. 2013; ${ }^{2}$ Ghaffari et al. 2014; ${ }^{3}$ Gemma et al. 2009; ${ }^{4}$ Thakali et al. 2014; ${ }^{5}$ Guénard et al. 2013; ${ }^{6}$ Edlow et al. $2014 ;{ }^{7}$ Nardelli et al. 2014; ${ }^{8}$ Basu et al. 2011; ${ }^{9}$ Haghiac et al. 2014; ${ }^{10}$ Collado et al. $2008 ;{ }^{11}$ Collado et al. $2010 ;{ }^{12}$ Challier et al. $2008 ;{ }^{13}$ Tsai et al. 2015; ${ }^{14}$ Oliva et al. 2012.)

Several transcriptomic and DNA methylation analyses have also suggested molecular mechanisms underlying fetal programming and offspring risk in the setting of maternal obesity. Global gene expression analysis of second trimester amniotic fluid supernatant in obese compared with lean women identified 205 significantly differentially expressed genes in fetuses of obese women. Gene expression patterns suggested dysregulation of genes related to lipid metabolism, inflammatory signaling, and neurodevelopment (see below) (Edlow et al. 2014). Evaluation of umbilical cord gene methylation and gene expression has also showed a significant effect of maternal obesity on the fetus (Gemma et al. 2009; Godfrey et al. 2011; Thakali et al. 2014). Maternal prepregnancy BMI was found to be positively correlated with methylation of the peroxisome proliferator-activated receptor gamma (PPAR $\gamma) \mathrm{C} 1 \mathrm{~A}$ promoter in the umbilical cord of newborns (Gemma et al. 2009). PPAR $\gamma$ is known to be involved in cellular assimilation of lipids via anabolic pathways, and PPAR $\gamma$ gene variants have been found to be associated with the abnormal lipid and carbohydrate metabolism that characterizes metabolic syndrome (Semple et al. 2006). An umbilical cord transcriptomic analysis showed differential expression of genes related to lipid, glucose, and protein metabolism; insulin and inflammatory signaling; and vascular reactivity in term fetuses of overweight and obese women (Thakali et al. 2014). An examination of differential methylation in DNA extracted from umbilical cord blood leukocytes of newborns born to obese versus lean parents found that both maternal and paternal obesity were associated with altered methylation patterns in offspring (Soubry et al. 2013). Another study of umbilical cord blood and neonatal adiposity at birth showed that fe- 
tuses of obese mothers had higher percent body fat, insulin resistance, cord leptin levels, and proinflammatory cytokine levels than those born to lean women (Catalano et al. 2009). Interestingly, a study examining miRNA expression in the fetuses of obese compared with lean women at term found no significant differences in expression of miRNA in umbilical cord blood (Ghaffari et al.2014). The investigators concluded that mechanisms other than miRNA may underlie the association between maternal obesity and fetal developmental programming. This is in contrast to a study that reported a specific miRNA signature associated with maternal obesity, although these investigators examined the amnion rather than umbilical cord blood. (Nardelli et al. 2014).

\section{MATERNAL OBESITY AND OFFSPRING NEURODEVELOPMENT}

\section{Data from Epidemiological Studies}

The adverse impact of maternal obesity on intrauterine programming of the fetus appears to extend beyond the cardiovascular and endocrine systems to the central nervous system. Compelling data from large epidemiologic studies suggest an association between maternal obesity and adverse neurodevelopmental outcomes in human offspring. These adverse outcomes include:

1. Increased odds of developing autism spectrum disorders in offspring of obese women or those with large GWG compared with controls (Krakowiak et al. 2012; Bilder et al. 2013; Reynolds et al. 2014). Obese mothers were $\sim 70 \%$ more likely to have a child with autism spectrum disorder compared with their lean counterparts (Krakowiak et al. 2012).

2. Increased odds of mild intellectual disability or cognitive deficits in children of obese women noted in several United States cohorts (Neggers et al. 2003; Tanda et al. 2012; Huang et al. 2014; Paulson et al. 2014) as well as in United Kingdom (Basatemur et al. 2013) and Finnish birth cohorts (Heikura et al. 2008). Obese women were twice as likely to have a child with developmental delay
(Tanne 2012). Excessive GWG was found to augment the association with lower child IQ (Huang et al. 2014).

3. A dose-dependent increase in ADHD symptoms in children was noted in prospective pregnancy cohorts from Sweden, Denmark, and Finland as maternal prepregnancy BMI increased from overweight to obese (Rodriguez et al. 2008). Excessive GWG was noted to have a synergistic effect with maternal prepregnancy obesity on increased incidence of ADHD in offspring (Rodriguez et al. 2008).

4. An association between maternal obesity and schizophrenia in adult offspring has been noted in a large retrospective cohort study (Schaefer et al. 2000), but other studies have failed to confirm this association (Khandaker et al. 2012).

5. A dose-dependent increase in relative risk of cerebral palsy in offspring has been noted as maternal BMI increased from overweight to morbidly obese (Ahlin et al. 2013; Crisham Janik et al. 2013; Mehta et al. 2014; Pan et al. 2014).

The mechanisms by which maternal obesity might result in adverse neurodevelopmental outcomes for offspring remain unclear. Putative mechanisms include excess circulating maternal free fatty acids or glucose (from dietary intake); maternal deficiencies of Vitamin D, B12, folate, and/or iron; n-3/n-6 fatty acid imbalance or relative n-3 fatty acid deficiency, alterations in serotonergic and dopaminergic signaling; and a proinflammatory, lipotoxic environment for the developing fetal brain (Bilbo and Tsang 2010; Sullivan et al. 2010, 2014; Bernard et al. 2013; Heerwagen et al. 2013; Kang et al. 2014; Mehta et al. 2014; Szostak-Wegierek 2014). Data from animal models and the use of molecular techniques to analyze human samples have provided further insights into the possible underlying mechanisms.

\section{Animal Models: Mechanistic Insights}

In utero nutritional imbalances and resulting growth restriction or macrosomia have both 
been linked to abnormal hypothalamic neurohormonal signaling in offspring (Ornoy 2011). Unique brain gene expression signatures and alterations in hypothalamic orexigenic signaling have also been noted in fetuses of obese dams, with changes in the expression of gene clusters associated with myelination, insulin signaling and metabolism, among others (Stachowiak et al. 2013a). Alteration of specific fetal brain networks related to hunger and satiety signaling could therefore be one factor contributing to both metabolic and neurodevelopmental morbidity in offspring (Stachowiak et al. 2013a). The same investigators noted structural brain changes including diminished proliferation, migration, and maturation of stem-like cells in fetal brains of obese dams, which they hypothesized, might predispose offspring to neurodevelopmental abnormalities (Stachowiak et al. 2013a).

Consumption of dietary fats has been shown in multiple rodent models to promote hypothalamic resistance to the anorexigenic hormones, leptin, and insulin (Munzberg et al. 2004; De Souza et al. 2005; Milanski et al. 2009). This is thought to be a consequence of diet-induced proinflammatory signaling (Moraes et al. 2009). Inflammatory signal transduction may activate apoptotic signaling pathways. Consistent with this concept, increased apoptosis of hypothalamic neurons and increased hypothalamic expression of proapoptotic genes has been noted in rats fed a HFD (Moraes et al. 2009). The same mechanisms may be recapitulated in offspring, particularly as dysregulation of leptin and insulin signaling and inflammation have been noted in fetuses and pups of obese dams.

Dysregulated leptin signaling has significant neurodevelopmental consequences. Leptin is a critical neurotrophic factor during development, and abnormalities in leptin signaling may lead to reduced neuronal stem cell differentiation and growth (Coupe et al. 2010; Desai et al. 2011a,b; Desai and Ross 2011) and impaired development of satiety pathways in the fetus (Bouret and Simerly 2004; Desai et al. 2011b). Reduced hypothalamic leptin-dependent signal transducer and activator of transcription 3 (STAT3) phosphorylation has been noted in mo- lecular analyses of fetal and offspring brains exposed to maternal obesity and HFD in utero (Ferezou-Viala et al. 2007; Franco et al. 2012; Sun et al. 2012). The effects of maternal HFD and obesity on the hypothalamus are not limited to appetite-related signaling. High maternal intake of (n-6) polyunsaturated fatty acids (PUFAs) during pregnancy led to increased locomotor activity and aggression in offspring, and increased (n-6) PUFA-induced protein kinase C (PKC) activity in the hypothalamus (Raygada et al. 1998).

The hippocampus is another brain region affected by maternal obesity in animal studies. Rodent models have shown impaired hippocampal growth, dysregulated hippocampal progenitor cell proliferation, and decreased hippocampal apoptosis in fetuses and pups of dams on a HFD (Niculescu and Lupu 2009; Tozuka et al. 2009, 2010) Molecular changes in the offspring hippocampus were associated with increased anxiety behavior in a mouse model of maternal HFD exposure (Peleg-Raibstein et al. 2012). Maternal obesity was found to induce lipid peroxidation in the early postnatal offspring hippocampus, and was associated with impaired hippocampal brain-derived neurotrophic factor (BDNF) production and dendritic arborization of new hippocampal neurons in a murine model (Tozuka et al. 2010). These hippocampal structural changes were associated with impaired acquisition of spatial learning in the pups.

Like the metabolic programming effects of maternal obesity, many of the harmful neurodevelopmental consequences of maternal obesity may be mediated by inflammation. The impact of inflammation on offspring neurodevelopment has been well-characterized in the setting of chorioamnionitis and adverse outcomes such as cerebral palsy (Wu and Colford 2000). Obesity is an inflammatory condition characterized by chronic activation of the innate immune system, with high levels of circulating proinflammatory cytokines (Mehta et al. 2014). Some investigators have proposed that this inflammatory environment results in increased metabolic stress and subsequent lipotoxicity, which may be mediating the abnormal neurodevelopment (Jarvie 
et al. 2010). Increased glial activation and oxidative stress has been reported in the cortex of rats born to dams fed a HFD (White et al. 2009). The developing serotoninergic and dopaminergic systems have also been shown to be sensitive to high levels of circulating inflammatory cytokines (Sullivan et al. 2014). Dysregulation of the serotonergic and dopaminergic systems (Sullivan et al. 2010; Vucetic and Reyes 2010; Vucetic et al. 2010), leading to mood disorders and reward-based eating, may perpetuate a vicious cycle in the offspring of obese females (Dallman et al. 2005; Adam and Epel 2007; Maniam and Morris 2010).

\section{Human Studies: Mechanistic Insights}

There are limited human data available that provide insights into the molecular mechanisms underlying neurodevelopmental morbidity in offspring (Fig. 2). In a study using cell-free RNA extracted from mid-trimester amniotic fluid supernatant of obese and lean women, global gene expression analysis showed significant upregulation of the central nervous system-specific gene Apolipoprotein D (APOD) (Edlow et al. 2014). This gene is highly expressed in fetal central nervous system tissues (Drayna et al. 1986; Seguin et al. 1995), and its protein product, ApoD, has been shown to exert neuroprotective effects in cell culture and in a rodent model of excitotoxic brain injury, possibly by protecting against oxidative stress (Franz et al. 1999; He et al. 2009; Bajo-Graneras et al. 2011b). Overexpression of $A P O D$ in fetuses of obese women may be a compensatory response to increased oxidative stress (Ganfornina et al. 2008; Bajo-Graneras et al. 2011a,b) or may itself be deleterious (Raygada et al. 1998; Khan et al. 2003; Dassati et al. 2014). Functional analysis of gene expression suggested significantly decreased apoptosis in fetuses of obese women, particularly in pathways related to the cerebral cortex and hippocampus. Because apoptosis is critical to normal neurodevelopment (Blaschke et al. 1998; Rice and Barone 2000; Depaepe et al. 2005), the investigators hypothesized that decreased apoptosis may be one of the mechanisms mediating abnormal neurodevelopment in offspring of obese women
(Edlow et al. 2014). Taken together, these findings suggest that the neurodevelopmental abnormalities noted in offspring of obese women may be mediated in part by decreased brain apoptosis and increased oxidative stress during critical developmental periods.

Supporting the concept that maternal obesity is associated with excessive oxidative stress in the fetus, RNA-Seq analysis of term placentas from obese and lean subjects found significant differences in gene expression, with obese placentas demonstrating expression patterns consistent with lipotoxicity, increased inflammation, and oxidative stress (Saben et al. 2014). Decreased expression of ferritin has also been noted in the placentas of obese human women compared with normal weight controls (Oliva et al. 2012). Decreased placental expression of ferritin may negatively impact the rate of iron uptake from the maternal circulation and transfer to the fetal circulation. Human studies have shown evidence of impaired iron status in newborns of obese women (Phillips et al. 2014) and in infants born to diabetic mothers (Siddappa et al. 2004). Iron deficiency is known to be associated with impaired brain development (Lozoff et al. 1991). Thus, decreased placental expression of ferritin and subsequent relative iron deficiency in the fetus may provide another mechanistic explanation for altered brain development in fetuses of obese women. More research in human fluids and tissues is needed to further elucidate molecular mechanisms underlying the increased risk for neurodevelopmental morbidity observed in offspring of obese women.

\section{SEX-SPECIFIC EFFECTS OF MATERNAL OBESITY OR HIGH-FAT DIET ON FETAL PROGRAMMING}

\section{Cardiometabolic Programming}

Diet-induced maternal obesity has been shown to induce sex-specific effects on fetal metabolic phenotype, gene expression, and epigenetic regulation in rodent models and human placentas (Gabory et al. 2012; Dahlhoff et al. 2014; Walker et al. 2014). For example, in a murine model of 
maternal HFD consumption, early life catch-up growth and associated increased adiposity, impaired glucose tolerance and reduced insulin sensitivity occurred only in male offspring ( Vuguin et al. 2013). In another murine model of maternal pregestational obesity and gestational HFD exposure, male adult offspring developed overweight, insulin resistance, hyperleptinemia, hyperuricemia, and hepatic steatosis. Females also showed impaired fasting glucose, but had reduced fat mass and adipocyte size (Dahlhoff et al. 2014). Another study also showed increased adiposity of male offspring exposed to a HFD during gestation, regardless of postweaning diet, whereas female offspring adiposity was more amenable to reversal with a control postweaning diet (Burgueno et al. 2013). Consistent with these findings of more adverse cardiometabolic effects for male offspring, examination of placentas in obese versus control mice found increased macrophage activation and cytokine gene expression in placentas of male fetuses exposed to maternal obesity (Kim et al. 2014).

There are conflicting data on increased versus decreased vulnerability of female offspring to cardiometabolic programming in the setting of maternal obesity. One study found that female offspring exposed to a HFD in utero and weaned to a junk food diet had lower mean arterial and diastolic pressure than controls (Mitra et al. 2009). However, other studies have suggested that female offspring have greater vulnerability to certain adverse cardiometabolic outcomes when exposed to maternal obesity or HFD in utero. For example, in a rat model, female offspring developed hypertension if exposed to a HFD during gestation or lactation, whereas male offspring did not (Khan et al. 2005). In another rodent study, female offspring were found to have greater adiposity than males even when fed a control diet postweaning, and had more elevated C-reactive protein levels (Elahi et al. 2009). Transcriptomic profiling of pup livers exposed to maternal Western-style diet in utero found significant changes in hepatic gene expression profiles compared with controls, but also a striking sexual dimorphism. Males showed alterations of genes related to developmental signaling (such as Wnt/beta-catenin signaling), whereas females showed altered expression of genes related to cholesterol synthesis and lipid metabolism (Mischke et al. 2013).

\section{Neurodevelopmental Programming}

Sexually dimorphic effects of maternal obesity on fetal neurodevelopment have also been noted. In an obese swine model, lower hypothalamic expression of anorexigenic peptides (leptin receptor and proopiomelanocortin) was noted in female but not male offspring exposed to a restricted diet in utero (Ovilo et al. 2014). The female offspring later developed increased adiposity in adulthood, suggesting a femalespecific programming effect of maternal obesity and response to gestational diet. In a murine model, exposure to maternal HFD during gestation and lactation resulted in increased hyperactivity in male offspring, and increased anxiety and decreased sociability in female offspring (Kang et al. 2014). Amelioration of the female, but not the male, neurobehavioral phenotype was noted after switching dams to a control diet during lactation. A control diet during lactation also decreased microglial activation and reduced proinflammatory cytokines in female offspring (Kang et al. 2014). In a nonhuman primate model of maternal obesity, perturbations in serotonergic signaling were noted in offspring, which predisposed female offspring to increased anxiety (Sullivan et al. 2010). However, in a rat model of maternal HFD, male offspring displayed increased anxiety and deficits in spatial learning compared with female offspring and controls (Bilbo and Tsang 2010). Thus, it is clear that some programming effects of maternal obesity and maternal HFD are sexspecific, but it remains unclear whether one sex is more adversely affected from a metabolic and neurodevelopmental standpoint.

\section{CONCLUDING REMARKS}

As maternal obesity and HFD consumption increase worldwide, future generations will continue to be at risk for metabolic and neurodevelopmental morbidities. Elucidating the molecular underpinnings of fetal and offspring 
morbidity is crucial in designing effective therapeutic strategies that can prevent or ameliorate maternal obesity-induced malprogramming.

\section{REFERENCES}

Aagaard-Tillery KM, Grove K, Bishop J, Ke X, Fu Q, McKnight R, Lane RH. 2008. Developmental origins of disease and determinants of chromatin structure: Maternal diet modifies the primate fetal epigenome. J Mol Endocrinol 41: 91-102.

Adam TC, Epel ES. 2007. Stress, eating and the reward system. Physiol Behav 91: 449-458.

Ahlin K, Himmelmann K, Hagberg G, Kacerovsky M, Cobo T, Wennerholm UB, Jacobsson B. 2013. Non-infectious risk factors for different types of cerebral palsy in termborn babies: A population-based, case-control study. BJOG 120: 724-731.

Alfaradhi MZ, Ozanne SE. 2011. Developmental programming in response to maternal overnutrition. Front Genet 2: 27 .

Armitage JA, Poston L, Taylor PD. 2008. Developmental origins of obesity and the metabolic syndrome: The role of maternal obesity. Front Horm Res 36: 73-84.

Arnal ME, Zhang J, Messori S, Bosi P, Smidt H, Lalles JP. 2014. Early changes in microbial colonization selectively modulate intestinal enzymes, but not inducible heat shock proteins in young adult swine. PLOS ONE 9: e87967.

Bajo-Graneras R, Ganfornina MD, Martin-Tejedor E, Sanchez D. 2011a. Apolipoprotein D mediates autocrine protection of astrocytes and controls their reactivity level, contributing to the functional maintenance of paraquatchallenged dopaminergic systems. Glia 59: 1551-1566.

Bajo-Graneras R, Sanchez D, Gutierrez G, Gonzalez C, Do Carmo S, Rassart E, Ganfornina MD. 2011b. Apolipoprotein $\mathrm{D}$ alters the early transcriptional response to oxidative stress in the adult cerebellum. J Neurochem 117: 949-960.

Barisione M, Carlini F, Gradaschi R, Camerini G, Adami GF. 2012. Body weight at developmental age in siblings born to mothers before and after surgically induced weight loss. Surg Obes Relat Dis 8: 387-391.

Barker DJ. 1995. Fetal origins of coronary heart disease. BMJ 311: $171-174$.

Barker DJ, Osmond C, Simmonds SJ, Wield GA. 1993. The relation of small head circumference and thinness at birth to death from cardiovascular disease in adult life. $B M$ 306: $422-426$.

Basatemur E, Gardiner J, Williams C, Melhuish E, Barnes J, Sutcliffe A. 2013. Maternal prepregnancy BMI and child cognition: A longitudinal cohort study. Pediatrics 131: 56-63.

Basu S, Haghiac M, Surace P, Challier JC, Guerre-Millo M, Singh K, Waters T, Minium J, Presley L, Catalano PM, et al. 2011. Pregravid obesity associates with increased maternal endotoxemia and metabolic inflammation. Obesity (Silver Spring) 19: 476-482.

Benatti RO, Melo AM, Borges FO, Ignacio-Souza LM, Simino LA, Milanski M, Velloso LA, Torsoni MA, Torsoni AS.
2014. Maternal high-fat diet consumption modulates hepatic lipid metabolism and microRNA-122 (miR-122) and microRNA-370 (miR-370) expression in offspring. Br J Nutr 111: 2112-2122.

Bernard JY, De Agostini M, Forhan A, de Lauzon-Guillain B, Charles MA, Heude B, Group EM-CCS. 2013. The dietary n6:n3 fatty acid ratio during pregnancy is inversely associated with child neurodevelopment in the EDEN mother-child cohort. J Nutr 143: 1481-1488.

Bilbo SD, Tsang V. 2010. Enduring consequences of maternal obesity for brain inflammation and behavior of offspring. FASEB J 24: 2104-2115.

Bilder DA, Bakian AV, Viskochil J, Clark EA, Botts EL, Smith KR, Pimentel R, McMahon WM, Coon H. 2013. Maternal prenatal weight gain and autism spectrum disorders. Pediatrics 132: e1276-e1283.

Blaschke AJ, Weiner JA, Chun J. 1998. Programmed cell death is a universal feature of embryonic and postnatal neuroproliferative regions throughout the central nervous system. J Comp Neurol 396: 39-50.

Boehm M, Slack FJ. 2006. MicroRNA word space control of lifespan and metabolism. Cell Cycle 5: 837-840.

Boney CM, Verma A, Tucker R, Vohr BR. 2005. Metabolic syndrome in childhood: Association with birth weight, maternal obesity, and gestational diabetes mellitus. Pediatrics 115: e290-e296.

Borengasser SJ, Zhong Y, Kang P, Lindsey F, Ronis MJ, Badger TM, Gomez-Acevedo H, Shankar K. 2013. Materna obesity enhances white adipose tissue differentiation and alters genome-scale DNA methylation in male rat offspring. Endocrinology 154: 4113-4125.

Borengasser SJ, Kang P, Faske J, Gomez-Acevedo H, Blackburn ML, Badger TM, Shankar K. 2014. High fat diet and in utero exposure to maternal obesity disrupts circadian rhythm and leads to metabolic programming of liver in rat offspring. PLoS ONE 9: e84209.

Bouret SG, Simerly RB. 2004. Minireview: Leptin and development of hypothalamic feeding circuits. Endocrinology 145: 2621-2626.

Bruce KD, Cagampang FR, Argenton M, Zhang J, Ethirajan PL, Burdge GC, Bateman AC, Clough GF, Poston L, Hanson MA, et al. 2009. Maternal high-fat feeding primes steatohepatitis in adult mice offspring, involving mitochondrial dysfunction and altered lipogenesis gene expression. Hepatology 50: 1796-1808.

Buckley AJ, Keseru B, Briody J, Thompson M, Ozanne SE, Thompson CH. 2005. Altered body composition and metabolism in the male offspring of high fat-fed rats. Metabolism 54: 500-507.

Burdge GC, Slater-Jefferies J, Torrens C, Phillips ES, Hanson MA, Lillycrop KA. 2007. Dietary protein restriction of pregnant rats in the $\mathrm{F}_{0}$ generation induces altered methylation of hepatic gene promoters in the adult male offspring in the $\mathrm{F}_{1}$ and $\mathrm{F}_{2}$ generations. Br J Nutr 97: 435439.

Burgueno AL, Cabrerizo R, Gonzales Mansilla N, Sookoian S, Pirola CJ. 2013. Maternal high-fat intake during pregnancy programs metabolic-syndrome-related phenotypes through liver mitochondrial DNA copy number and transcriptional activity of liver PPARGC1A. J Nutr Biochem 24: 6-13. 
Catalano PM, Ehrenberg HM. 2006. The short- and longterm implications of maternal obesity on the mother and her offspring. BJOG 113: 1126-1133.

Catalano PM, Thomas A, Huston-Presley L, Amini SB. 2003. Increased fetal adiposity: A very sensitive marker of abnormal in utero development. Am J Obstet Gynecol 189: $1698-1704$

Catalano PM, Presley L, Minium J, Hauguel-de Mouzon S. 2009. Fetuses of obese mothers develop insulin resistance in utero. Diabetes Care 32: 1076-1080.

Cerf ME, Williams K, Nkomo XI, Muller CJ, Du Toit DF, Louw J, Wolfe-Coote SA. 2005. Islet cell response in the neonatal rat after exposure to a high-fat diet during pregnancy. Am J Physiol Regul Integr Comp Physiol 288: R1122-R1128.

Cerf ME, Muller CJ, Du Toit DF, Louw J, Wolfe-Coote SA. 2006. Hyperglycaemia and reduced glucokinase expression in weanling offspring from dams maintained on a high-fat diet. Br J Nutr 95: 391-396.

Cerf ME, Chapman CS, Muller CJ, Louw J. 2009. Gestational high-fat programming impairs insulin release and reduces Pdx-1 and glucokinase immunoreactivity in neonatal Wistar rats. Metabolism 58: 1787-1792.

Challier JC, Basu S, Bintein T, Minium J, Hotmire K, Catalano PM, Hauguel-de Mouzon S. 2008. Obesity in pregnancy stimulates macrophage accumulation and inflammation in the placenta. Placenta 29: 274-281.

Chow J, Lee SM, Shen Y, Khosravi A, Mazmanian SK. 2010. Host-bacterial symbiosis in health and disease. $A d v$ Immunol 107: 243-274.

Collado MC, Isolauri E, Laitinen K, Salminen S. 2008. Distinct composition of gut microbiota during pregnancy in overweight and normal-weight women. Am J Clin Nutr 88: 894-899.

Collado MC, Isolauri E, Laitinen K, Salminen S. 2010. Effect of mother's weight on infant's microbiota acquisition, composition, and activity during early infancy: A prospective follow-up study initiated in early pregnancy. Am J Clin Nutr 92: 1023-1030.

Coupe B, Amarger V, Grit I, Benani A, Parnet P. 2010. Nutritional programming affects hypothalamic organization and early response to leptin. Endocrinology 151: $702-713$.

Crisham Janik MD, Newman TB, Cheng YW, Xing G, Gilbert WM, Wu YW. 2013. Maternal diagnosis of obesity and risk of cerebral palsy in the child. J Pediatr 163: 13071312.

Dahlhoff M, Pfister S, Blutke A, Rozman J, Klingenspor M, Deutsch MJ, Rathkolb B, Fink B, Gimpfl M, Hrabe de Angelis M, et al. 2014. Peri-conceptional obesogenic exposure induces sex-specific programming of disease susceptibilities in adult mouse offspring. Biochim Biophys Acta 1842: 304-317.

Dallman MF, Pecoraro NC, la Fleur SE. 2005. Chronic stress and comfort foods: Self-medication and abdominal obesity. Brain Behav Immun 19: 275-280.

Dassati S, Waldner A, Schweigreiter R. 2014. Apolipoprotein $D$ takes center stage in the stress response of the aging and degenerative brain. Neurobiol Aging 35: 1632-1642.

De Souza CT, Araujo EP, Bordin S, Ashimine R, Zollner RL, Boschero AC, Saad MJ, Velloso LA. 2005. Consumption of a fat-rich diet activates a proinflammatory response and induces insulin resistance in the hypothalamus. Endocrinology 146: 4192-4199.

Depaepe V, Suarez-Gonzalez N, Dufour A, Passante L, Gorski JA, Jones KR, Ledent C, Vanderhaeghen P. 2005. Ephrin signalling controls brain size by regulating apoptosis of neural progenitors. Nature 435: 1244-1250.

Desai M, Ross MG. 2011. Fetal programming of adipose tissue: Effects of intrauterine growth restriction and maternal obesity/high-fat diet. Semin Reprod Med 29: 237 245.

Desai M, Li T, Ross MG. 2011a. Fetal hypothalamic neuroprogenitor cell culture: Preferential differentiation paths induced by leptin and insulin. Endocrinology 152: 3192 3201.

Desai M, Li T, Ross MG. 2011b. Hypothalamic neurosphere progenitor cells in low birth-weight rat newborns: Neurotrophic effects of leptin and insulin. Brain Res 1378: 29-42.

Drayna D, Fielding C, McLean J, Baer B, Castro G, Chen E, Comstock L, Henzel W, Kohr W, Rhee L, et al. 1986. Cloning and expression of human apolipoprotein D cDNA. J Biol Chem 261: 16535-16539.

Dulloo AG, Jacquet J, Solinas G, Montani JP, Schutz Y. 2010. Body composition phenotypes in pathways to obesity and the metabolic syndrome. Int J Obes (Lond) 34: S4S17.

Edlow AG, Bianchi DW. 2012. Tracking fetal development through molecular analysis of maternal biofluids. Biochim Biophys Acta 1822: 1970-1980.

Edlow AG, Vora NL, Hui L, Wick HC, Cowan JM, Bianchi DW. 2014. Maternal obesity affects fetal neurodevelopmental and metabolic gene expression: A pilot study. PLOS ONE 9: e88661.

Elahi MM, Matata BM. 2014. Gender differences in the expression of genes involved during cardiac development in offspring from dams on high fat diet. Mol Biol Rep 41: 7209-7216.

Elahi MM, Cagampang FR, Mukhtar D, Anthony FW, Ohri SK, Hanson MA. 2009. Long-term maternal high-fat feeding from weaning through pregnancy and lactation predisposes offspring to hypertension, raised plasma lipids and fatty liver in mice. Br J Nutr 102: 514-519.

Fak F, Ahrne S, Molin G, Jeppsson B, Westrom B. 2008. Microbial manipulation of the rat dam changes bacterial colonization and alters properties of the gut in her offspring. Am J Physiol Gastrointest Liver Physiol 294: G148G154.

Ferezou-Viala J, Roy AF, Serougne C, Gripois D, Parquet M, Bailleux V, Gertler A, Delplanque B, Djiane J, Riottot M, et al. 2007. Long-term consequences of maternal high-fat feeding on hypothalamic leptin sensitivity and diet-induced obesity in the offspring. Am J Physiol Regul Integr Comp Physiol 293: R1056-R1062.

Flegal KM, Carroll MD, Kit BK, Ogden CL. 2012. Prevalence of obesity and trends in the distribution of body mass index among US adults, 1999-2010. JAMA 307: 491497.

Franco JG, Fernandes TP, Rocha CP, Calvino C, PazosMoura CC, Lisboa PC, Moura EG, Trevenzoli IH. 2012. Maternal high-fat diet induces obesity and adrenal and 
thyroid dysfunction in male rat offspring at weaning. $J$ Physiol 590: 5503-5518.

Franz G, Reindl M, Patel SC, Beer R, Unterrichter I, Berger T, Schmutzhard E, Poewe W, Kampfl A. 1999. Increased expression of apolipoprotein $\mathrm{D}$ following experimental traumatic brain injury. J Neurochem 73: 1615-1625.

Gabory A, Ferry L, Fajardy I, Jouneau L, Gothie JD, Vige A, Fleur C, Mayeur S, Gallou-Kabani C, Gross MS, et al. 2012. Maternal diets trigger sex-specific divergent trajectories of gene expression and epigenetic systems in mouse placenta. PLoS ONE 7: e47986.

Ganfornina MD, Do Carmo S, Lora JM, Torres-Schumann S, Vogel M, Allhorn M, Gonzalez C, Bastiani MJ, Rassart E, Sanchez D. 2008. Apolipoprotein D is involved in the mechanisms regulating protection from oxidative stress. Aging Cell 7: 506-515.

Ganu RS, Harris RA, Collins K, Aagaard KM. 2012. Early origins of adult disease: Approaches for investigating the programmable epigenome in humans, nonhuman primates, and rodents. ILAR J 53: 306-321.

Gauthier BR, Wollheim CB. 2006. MicroRNAs: 'Ribo-regulators' of glucose homeostasis. Nat Med 12: 36-38.

Gemma C, Sookoian S, Alvarinas J, Garcia SI, Quintana L, Kanevsky D, Gonzalez CD, Pirola CJ. 2009. Maternal pregestational BMI is associated with methylation of the PPARGC1A promoter in newborns. Obesity (Silver Spring) 17: 1032-1039.

Ghaffari N, Parry S, Elovitz MA, Durnwald CP. 2014. The effect of an obesogenic maternal environment on expression of fetal umbilical cord blood miRNA. Reprod Sci doi: $10.1177 / 1933719114565032$.

Gillman MW, Rifas-Shiman S, Berkey CS, Field AE, Colditz GA. 2003. Maternal gestational diabetes, birth weight, and adolescent obesity. Pediatrics 111: e221-e226.

Gluckman PD, Hanson MA, Cooper C, Thornburg KL. 2008. Effect of in utero and early-life conditions on adult health and disease. N Engl J Med 359: 61-73.

Godfrey KM, Sheppard A, Gluckman PD, Lillycrop KA, Burdge GC, McLean C, Rodford J, Slater-Jefferies JL, Garratt E, Crozier SR, et al. 2011. Epigenetic gene promoter methylation at birth is associated with child's later adiposity. Diabetes 60: 1528-1534.

Gohir W, Ratcliffe EM, Sloboda DM. 2014. Of the bugs that shape us: Maternal obesity, the gut microbiome, and long-term disease risk. Pediatr Res 77: 196-204.

Gregorio BM, Souza-Mello V, Carvalho JJ, Mandarim-deLacerda CA, Aguila MB. 2010. Maternal high-fat intake predisposes nonalcoholic fatty liver disease in C57BL/6 offspring. Am J Obstet Gynecol 203: e491-e498.

Guénard F, Deshaies Y, Cianflone K, Kral JG, Marceau P, Vohl MC. 2013. Differential methylation in glucoregulatory genes of offspring born before vs. after maternal gastrointestinal bypass surgery. Proc Natl Acad Sci 110: 11439-11444.

Haghiac M, Basu S, Presley L, Serre D, Catalano PM, Hauguel-de Mouzon S. 2014. Patterns of adiponectin expression in term pregnancy: Impact of obesity. J Clin Endocrinol Metab 99: 3427-3434.

Hales CN, Barker DJ. 1992. Type 2 (non-insulin-dependent) diabetes mellitus: The thrifty phenotype hypothesis. $D i-$ abetologia 35: 595-601.
Harris K, Kassis A, Major G, Chou CJ. 2012. Is the gut microbiota a new factor contributing to obesity and its metabolic disorders? J Obes 2012: 879151.

Hartil K, Vuguin PM, Kruse M, Schmuel E, Fiallo A, Vargas C, Warner MJ, Durand JL, Jelicks LA, Charron MJ. 2009. Maternal substrate utilization programs the development of the metabolic syndrome in male mice exposed to high fat in utero. Pediatr Res 66: 368-373.

He X, Jittiwat J, Kim JH, Jenner AM, Farooqui AA, Patel SC, Ong WY. 2009. Apolipoprotein D modulates $\mathrm{F}_{2}$-isoprostane and 7-ketocholesterol formation and has a neuroprotective effect on organotypic hippocampal cultures after kainate-induced excitotoxic injury. Neurosci Lett 455: $183-186$.

Heerwagen MJ, Miller MR, Barbour LA, Friedman JE. 2010. Maternal obesity and fetal metabolic programming: A fertile epigenetic soil. Am J Physiol Regul Integr Comp Physiol 299: R711-R722.

Heerwagen MJ, Stewart MS, de la Houssaye BA, Janssen RC, Friedman JE. 2013. Transgenic increase in N-3/N-6 fatty acid ratio reduces maternal obesity-associated inflammation and limits adverse developmental programming in mice. PLoS ONE 8: e67791.

Heikura U, Taanila A, Hartikainen AL, Olsen P, Linna SL, von Wendt L, Jarvelin MR. 2008. Variations in prenatal sociodemographic factors associated with intellectual disability: A study of the 20-year interval between two birth cohorts in northern Finland. Am J Epidemiol 167: 169-177.

Hinkle SN, Schieve LA, Stein AD, Swan DW, Ramakrishnan U, Sharma AJ. 2012. Associations between maternal prepregnancy body mass index and child neurodevelopment at 2 years of age. Int J Obes (Lond) 36: 1312-1319.

Hochner H, Friedlander Y, Calderon-Margalit R, Meiner V, Sagy Y, Avgil-Tsadok M, Burger A, Savitsky B, Siscovick DS, Manor O. 2012. Associations of maternal prepregnancy body mass index and gestational weight gain with adult offspring cardiometabolic risk factors: The Jerusalem perinatal family follow-up study. Circulation 125: 1381-1389.

Hoile SP, Irvine NA, Kelsall CJ, Sibbons C, Feunteun A, Collister A, Torrens C, Calder PC, Hanson MA, Lillycrop KA, et al. 2013. Maternal fat intake in rats alters 20:4n-6 and 22:6n-3 status and the epigenetic regulation of Fads2 in offspring liver. J Nutr Biochem 24: 1213-1220.

Howie GJ, Sloboda DM, Kamal T, Vickers MH. 2009. Maternal nutritional history predicts obesity in adult offspring independent of postnatal diet. J Physiol 587: 905-915.

Huang L, Yu X, Keim S, Li L, Zhang L, Zhang J. 2014. Maternal prepregnancy obesity and child neurodevelopment in the Collaborative Perinatal Project. Int J Epidemiol 43: 783-792.

Hui L, Wick HC, Edlow AG, Cowan JM, Bianchi DW. 2013. Global gene expression analysis of term amniotic fluid cell-free fetal RNA. Obstet Gynecol 121: 1248-1254.

Jarvie E, Hauguel-de-Mouzon S, Nelson SM, Sattar N, Catalano PM, Freeman DJ. 2010. Lipotoxicity in obese pregnancy and its potential role in adverse pregnancy outcome and obesity in the offspring. Clin Sci (Lond) 119: $123-129$. 
Jehn M, Brewis A. 2009. Paradoxical malnutrition in mother-child pairs: Untangling the phenomenon of over- and under-nutrition in underdeveloped economies. Econ Hum Biol 7: 28-35.

John B, Enright AJ, Aravin A, Tuschl T, Sander C, Marks DS 2004. Human MicroRNA targets. PLoS Biol 2: e363.

Jones HN, Woollett LA, Barbour N, Prasad PD, Powell TL, Jansson T. 2009. High-fat diet before and during pregnancy causes marked up-regulation of placental nutrient transport and fetal overgrowth in C57/BL6 mice. FASEB J 23: $271-278$.

Kang SS, Kurti A, Fair DA, Fryer JD. 2014. Dietary intervention rescues maternal obesity induced behavior deficits and neuroinflammation in offspring. J Neuroinflammation 11: 156.

Kelly T, Yang W, Chen CS, Reynolds K, He J. 2008. Global burden of obesity in 2005 and projections to 2030. Int J Obes (Lond) 32: 1431-1437.

Khan MM, Parikh VV, Mahadik SP. 2003. Antipsychotic drugs differentially modulate apolipoprotein $\mathrm{D}$ in rat brain. J Neurochem 86: 1089-1100.

Khan IY, Dekou V, Douglas G, Jensen R, Hanson MA, Poston L, Taylor PD. 2005. A high-fat diet during rat pregnancy or suckling induces cardiovascular dysfunction in adult offspring. Am J Physiol Regul Integr Comp Physiol 288: R127-R133.

Khandaker GM, Dibben CR, Jones PB. 2012. Does maternal body mass index during pregnancy influence risk of schizophrenia in the adult offspring? Obes Rev 13: 518-527.

Kim SY, Dietz PM, England L, Morrow B, Callaghan WM. 2007. Trends in pre-pregnancy obesity in nine states, 1993-2003. Obesity (Silver Spring) 15: 986-993.

Kim DW, Young SL, Grattan DR, Jasoni CL. 2014. Obesity during pregnancy disrupts placental morphology, cell proliferation, and inflammation in a sex-specific manner across gestation in the mouse. Biol Reprod 90: 130.

Krakowiak P, Walker CK, Bremer AA, Baker AS, Ozonoff S, Hansen RL, Hertz-Picciotto I. 2012. Maternal metabolic conditions and risk for autism and other neurodevelopmental disorders. Pediatrics 129: e1121-e1128.

Kral JG, Biron S, Simard S, Hould FS, Lebel S, Marceau S, Marceau P. 2006. Large maternal weight loss from obesity surgery prevents transmission of obesity to children who were followed for 2 to 18 years. Pediatrics 118: e1644e1649.

Krasnow SM, Nguyen ML, Marks DL. 2011. Increased maternal fat consumption during pregnancy alters body composition in neonatal mice. Am J Physiol Endocrinol Metab 301: E1243-E1253.

Krek A, Grun D, Poy MN, Wolf R, Rosenberg L, Epstein EJ, MacMenamin P, da Piedade I, Gunsalus KC, Stoffel M, et al. 2005. Combinatorial microRNA target predictions. Nat Genet 37: 495-500.

Lanham SA, Roberts C, Hollingworth T, Sreekumar R, Elah MM, Cagampang FR, Hanson MA, Oreffo RO. 2010. Maternal high-fat diet: Effects on offspring bone structure. Osteoporos Int 21: 1703-1714.

Latouche C, Heywood SE, Henry SL, Ziemann M, Lazarus R, El-Osta A, Armitage JA, Kingwell BA. 2014. Maternal overnutrition programs changes in the expression of skel- etal muscle genes that are associated with insulin resistance and defects of oxidative phosphorylation in adult male rat offspring. J Nutr 144: 237-244.

Lawlor DA, Smith GD, O'Callaghan M, Alati R, Mamun AA, Williams GM, Najman JM. 2007. Epidemiologic evidence for the fetal overnutrition hypothesis: Findings from the mater-university study of pregnancy and its outcomes. Am J Epidemiol 165: 418-424.

Lewis BP, Shih IH, Jones-Rhoades MW, Bartel DP, Burge CB. 2003. Prediction of mammalian microRNA targets. Cell 115: 787-798.

Ley RE, Backhed F, Turnbaugh P, Lozupone CA, Knight RD, Gordon JI. 2005. Obesity alters gut microbial ecology. Proc Natl Acad Sci 102: 11070-11075.

Ley RE, Turnbaugh PJ, Klein S, Gordon JI. 2006. Microbial ecology: Human gut microbes associated with obesity. Nature 444: 1022-1023.

Li M, Sloboda DM, Vickers MH. 2011. Maternal obesity and developmental programming of metabolic disorders in offspring: Evidence from animal models. Exp Diabetes Res 2011: 592408.

Li M, Reynolds CM, Sloboda DM, Gray C, Vickers MH. 2013. Effects of taurine supplementation on hepatic markers of inflammation and lipid metabolism in mothers and offspring in the setting of maternal obesity. PLoS ONE 8: e76961.

Lillycrop KA, Phillips ES, Jackson AA, Hanson MA, Burdge GC. 2005. Dietary protein restriction of pregnant rats induces and folic acid supplementation prevents epigenetic modification of hepatic gene expression in the offspring. J Nutr 135: 1382-1386.

Loos RJ. 2009. Recent progress in the genetics of common obesity. Br J Clin Pharmacol 68: 811-829.

Lozoff B, Jimenez E, Wolf AW. 1991. Long-term developmental outcome of infants with iron deficiency. N Engl J Med 325: 687-694.

Luoto R, Collado MC, Salminen S, Isolauri E. 2013. Reshaping the gut microbiota at an early age: Functional impact on obesity risk? Ann Nutr Metab 63: 17-26.

Ma J, Prince AL, Bader D, Hu M, Ganu R, Baquero K, Blundell P, Alan Harris R, Frias AE, Grove KL, et al. 2014. High-fat maternal diet during pregnancy persistently alters the offspring microbiome in a primate model. Nat Commun 5: 3889.

Maloyan A, Muralimanoharan S, Huffman S, Cox LA, Nathanielsz PW, Myatt L, Nijland MJ. 2013. Identification and comparative analyses of myocardial miRNAs involved in the fetal response to maternal obesity. Physiol Genomics 45: 889-900.

Maniam J, Morris MJ. 2010. Palatable cafeteria diet ameliorates anxiety and depression-like symptoms following an adverse early environment. Psychoneuroendocrinology 35: $717-728$.

Masuyama H, Hiramatsu Y. 2012. Effects of a high-fat diet exposure in utero on the metabolic syndrome-like phenomenon in mouse offspring through epigenetic changes in adipocytokine gene expression. Endocrinology 153: 2823-2830.

Mehta SH, Kerver JM, Sokol RJ, Keating DP, Paneth N. 2014. The association between maternal obesity and neurode- 
velopmental outcomes of offspring. J Pediatr 165: 891896.

Milanski M, Degasperi G, Coope A, Morari J, Denis R, Cintra DE, Tsukumo DM, Anhe G, Amaral ME, Takahashi HK, et al. 2009. Saturated fatty acids produce an inflammatory response predominantly through the activation of TLR4 signaling in hypothalamus: Implications for the pathogenesis of obesity. J Neurosci 29: 359-370.

Mischke M, Pruis MG, Boekschoten MV, Groen AK, Fitri AR, van de Heijning BJ, Verkade HJ, Muller M, Plosch T, Steegenga WT. 2013. Maternal Western-style high fat diet induces sex-specific physiological and molecular changes in two-week-old mouse offspring. PLoS ONE 8: e78623.

Mitra A, Alvers KM, Crump EM, Rowland NE. 2009. Effect of high-fat diet during gestation, lactation, or postweaning on physiological and behavioral indexes in borderline hypertensive rats. Am J Physiol Regul Integr Comp Physiol 296: R20-R28.

Moraes JC, Coope A, Morari J, Cintra DE, Roman EA, Pauli JR, Romanatto T, Carvalheira JB, Oliveira AL, Saad MJ, et al. 2009. High-fat diet induces apoptosis of hypothalamic neurons. PLoS ONE 4: e5045.

Morris MJ, Chen H. 2009. Established maternal obesity in the rat reprograms hypothalamic appetite regulators and leptin signaling at birth. Int J Obes (Lond) 33: 115-122.

Munzberg H, Flier JS, Bjorbaek C. 2004. Region-specific leptin resistance within the hypothalamus of diet-induced obese mice. Endocrinology 145: 4880-4889.

Myles IA, Fontecilla NM, Janelsins BM, Vithayathil PJ, Segre JA, Datta SK. 2013. Parental dietary fat intake alters offspring microbiome and immunity. J Immunol 191: 3200-3209.

Nardelli C, Iaffaldano L, Ferrigno M, Labruna G, Maruotti GM, Quaglia F, Capobianco V, Di Noto R, Del Vecchio L, Martinelli P, et al. 2014. Characterization and predicted role of the microRNA expression profile in amnion from obese pregnant women. Int J Obes (Lond) 38: 466-469.

Nathanielsz PW, Poston L, Taylor PD. 2007. In utero exposure to maternal obesity and diabetes: Animal models that identify and characterize implications for future health. Clin Perinatol 34: 515-526.

Neggers YH, Goldenberg RL, Ramey SL, Cliver SP. 2003. Maternal prepregnancy body mass index and psychomotor development in children. Acta Obstet Gynecol Scand 82: $235-240$.

Ng SF, Lin RC, Maloney CA, Youngson NA, Owens JA, Morris MJ. 2014. Paternal high-fat diet consumption induces common changes in the transcriptomes of retroperitoneal adipose and pancreatic islet tissues in female rat offspring. FASEB J 28: 1830-1841.

Niculescu MD, Lupu DS. 2009. High fat diet-induced maternal obesity alters fetal hippocampal development. Int $J$ Dev Neurosci 27: 627-633.

Nohr EA, Vaeth M, Bech BH, Henriksen TB, Cnattingius S, Olsen J. 2007. Maternal obesity and neonatal mortality according to subtypes of preterm birth. Obstet Gynecol 110: $1083-1090$.

Oakley EJ, Van Zant G. 2007. Unraveling the complex regulation of stem cells: Implications for aging and cancer. Leukemia 21: 612-621.
Oken E, Rifas-Shiman SL, Field AE, Frazier AL, Gillman MW. 2008. Maternal gestational weight gain and offspring weight in adolescence. Obstet Gynecol 112: 9991006.

Oliva K, Barker G, Riley C, Bailey MJ, Permezel M, Rice GE, Lappas M. 2012. The effect of pre-existing maternal obesity on the placental proteome: Two-dimensional difference gel electrophoresis coupled with mass spectrometry. $J$ Mol Endocrinol 48: 139-149.

Ornoy A. 2011. Prenatal origin of obesity and their complications: Gestational diabetes, maternal overweight and the paradoxical effects of fetal growth restriction and macrosomia. Reprod Toxicol 32: 205-212.

Ovilo C, Gonzalez-Bulnes A, Benitez R, Ayuso M, Barbero A, Perez-Solana ML, Barragan C, Astiz S, Fernandez A, Lopez-Bote C. 2014. Prenatal programming in an obese swine model: Sex-related effects of maternal energy restriction on morphology, metabolism and hypothalamic gene expression. Br J Nutr 111: 735-746.

Pan C, Deroche CB, Mann JR, McDermott S, Hardin JW. 2014. Is prepregnancy obesity associated with risk of cerebral palsy and epilepsy in children? J Child Neurol 29: NP196-NP201.

Paulson JF, Mehta SH, Sokol RJ, Chauhan SP. 2014. Large for gestational age and long-term cognitive function. Am J Obstet Gynecol 210: e341-e344.

Peleg-Raibstein D, Luca E, Wolfrum C. 2012. Maternal highfat diet in mice programs emotional behavior in adulthood. Behav Brain Res 233: 398-404.

Petitt DJ, Bennett PH, Knowler WC, Baird HR, Aleck KA. 1985. Gestational diabetes mellitus and impaired glucose tolerance during pregnancy. Long-term effects on obesity and glucose tolerance in the offspring. Diabetes 34: 119122.

Phillips AK, Roy SC, Lundberg R, Guilbert TW, Auger AP, Blohowiak SE, Coe CL, Kling PJ. 2014. Neonatal iron status is impaired by maternal obesity and excessive weight gain during pregnancy. J Perinatol 34: 513-518.

Raygada M, Cho E, Hilakivi-Clarke L. 1998. High maternal intake of polyunsaturated fatty acids during pregnancy in mice alters offsprings' aggressive behavior, immobility in the swim test, locomotor activity and brain protein kinase C activity. J Nutr 128: 2505-2511.

Reynolds RM, Osmond C, Phillips DI, Godfrey KM. 2010. Maternal BMI, parity, and pregnancy weight gain: Influences on offspring adiposity in young adulthood. J Clin Endocrinol Metab 95: 5365-5369.

Reynolds RM, Allan KM, Raja EA, Bhattacharya S, McNeill G, Hannaford PC, Sarwar N, Lee AJ, Bhattacharya S, Norman JE. 2013. Maternal obesity during pregnancy and premature mortality from cardiovascular event in adult offspring: Follow-up of 1323275 person years. BMJ 347: f4539.

Reynolds LC, Inder TE, Neil JJ, Pineda RG, Rogers CE. 2014. Maternal obesity and increased risk for autism and developmental delay among very preterm infants. J Perinatol 34: 688-692.

Rice D, Barone S Jr, 2000. Critical periods of vulnerability for the developing nervous system: Evidence from humans and animal models. Environ Health Perspect 108: 511-533. 
Rodriguez A, Miettunen J, Henriksen TB, Olsen J, Obel C, Taanila A, Ebeling H, Linnet KM, Moilanen I, Jarvelin MR. 2008. Maternal adiposity prior to pregnancy is associated with ADHD symptoms in offspring: Evidence from three prospective pregnancy cohorts. Int J Obes (Lond) 32: 550-557.

Ross MG, Desai M. 2013. Developmental programming of offspring obesity, adipogenesis, and appetite. Clin Obstet Gynecol 56: 529-536.

Saben J, Lindsey F, Zhong Y, Thakali K, Badger TM, Andres A, Gomez-Acevedo H, Shankar K. 2014. Maternal obesity is associated with a lipotoxic placental environment. Placenta 35: 171-177.

Samuelsson AM, Matthews PA, Argenton M, Christie MR, McConnell JM, Jansen EH, Piersma AH, Ozanne SE, Twinn DF, Remacle C, et al. 2008. Diet-induced obesity in female mice leads to offspring hyperphagia, adiposity, hypertension, and insulin resistance: A novel murine model of developmental programming. Hypertension 51: 383-392.

Santacruz A, Collado MC, Garcia-Valdes L, Segura MT, Martin-Lagos JA, Anjos T, Marti-Romero M, Lopez RM, Florido J, Campoy C, et al. 2010. Gut microbiota composition is associated with body weight, weight gain and biochemical parameters in pregnant women. $\mathrm{Br} \mathrm{J}$ Nutr 104: 83-92.

Schaefer CA, Brown AS, Wyatt RJ, Kline J, Begg MD, Bresnahan MA, Susser ES. 2000. Maternal prepregnant body mass and risk of schizophrenia in adult offspring. Schizophr Bull 26: 275-286.

Schellong K, Schulz S, Harder T, Plagemann A. 2012. Birth weight and long-term overweight risk: Systematic review and a meta-analysis including 643,902 persons from 66 studies and 26 countries globally. PLoS ONE 7: e47776.

Schultz M, Gottl C, Young RJ, Iwen P, Vanderhoof JA. 2004 Administration of oral probiotic bacteria to pregnant women causes temporary infantile colonization. J Pediatr Gastroenterol Nutr 38: 293-297.

Seguin D, Desforges M, Rassart E. 1995. Molecular characterization and differential mRNA tissue distribution of mouse apolipoprotein D. Brain Res Mol Brain Res 30: $242-250$.

Semple RK, Chatterjee VK, O’Rahilly S. 2006. PPAR $\gamma$ and human metabolic disease. J Clin Invest 116: 581-589.

Shankar K, Kang P, Harrell A, Zhong Y, Marecki JC, Ronis MJ, Badger TM. 2010. Maternal overweight programs insulin and adiponectin signaling in the offspring. Endocrinology 151: 2577-2589.

Shankar K, Zhong Y, Kang P, Lau F, Blackburn ML, Chen JR, Borengasser SJ, Ronis MJ, Badger TM. 2011. Maternal obesity promotes a proinflammatory signature in rat uterus and blastocyst. Endocrinology 152: 4158-4170.

Siddappa AM, Georgieff MK, Wewerka S, Worwa C, Nelson CA, Deregnier RA. 2004. Iron deficiency alters auditory recognition memory in newborn infants of diabetic mothers. Pediatr Res 55: 1034-1041.

Smith J, Cianflone K, Biron S, Hould FS, Lebel S, Marceau S, Lescelleur O, Biertho L, Simard S, Kral JG, et al. 2009. Effects of maternal surgical weight loss in mothers on intergenerational transmission of obesity. J Clin Endocrinol Metab 94: 4275-4283.
Soubry A, Murphy SK, Wang F, Huang Z, Vidal AC, Fuemmeler BF, Kurtzberg J, Murtha A, Jirtle RL, Schildkraut JM, et al. 2013. Newborns of obese parents have altered DNA methylation patterns at imprinted genes. Int $J$ Obes (Lond) doi: 10.1038/ijo.2013.103.

Sparano S, Ahrens W, De Henauw S, Marild S, Molnar D, Moreno LA, Suling M, Tornaritis M, Veidebaum T, Siani A, et al. 2013. Being macrosomic at birth is an independent predictor of overweight in children: Results from the IDEFICS study. Matern Child Health J 17: 1373-1381.

Sridhar SB, Darbinian J, Ehrlich SF, Markman MA, Gunderson EP, Ferrara A, Hedderson MM. 2014. Maternal gestational weight gain and offspring risk for childhood overweight or obesity. Am J Obstet Gynecol 211: e251e258.

Stachowiak EK, Oommen S, Vasu VT, Srinivasan M, Stachowiak M, Gohil K, Patel MS. 2013a. Maternal obesity affects gene expression and cellular development in fetal brains. Nutr Neurosci 16: 96-103.

Stachowiak EK, Srinivasan M, Stachowiak MK, Patel MS. 2013b. Maternal obesity induced by a high fat diet causes altered cellular development in fetal brains suggestive of a predisposition of offspring to neurological disorders in later life. Metab Brain Dis 28: 721-725.

Strakovsky RS, Zhang X, Zhou D, Pan YX. 2011. Gestational high fat diet programs hepatic phosphoenolpyruvate carboxykinase gene expression and histone modification in neonatal offspring rats. J Physiol 589: 2707-2717.

Sullivan EL, Grayson B, Takahashi D, Robertson N, Maier A, Bethea CL, Smith MS, Coleman K, Grove KL. 2010. Chronic consumption of a high-fat diet during pregnancy causes perturbations in the serotonergic system and increased anxiety-like behavior in nonhuman primate offspring. J Neurosci 30: 3826-3830.

Sullivan EL, Smith MS, Grove KL. 2011. Perinatal exposure to high-fat diet programs energy balance, metabolism and behavior in adulthood. Neuroendocrinology 93: 1-8.

Sullivan EL, Nousen EK, Chamlou KA. 2014. Maternal high fat diet consumption during the perinatal period programs offspring behavior. Physiol Behav 123: 236-242.

Sun B, Purcell RH, Terrillion CE, Yan J, Moran TH, Tamashiro KL. 2012. Maternal high-fat diet during gestation or suckling differentially affects offspring leptin sensitivity and obesity. Diabetes 61: 2833-2841.

Suter M, Bocock P, Showalter L, Hu M, Shope C, McKnight R, Grove K, Lane R, Aagaard-Tillery K. 2011. Epigenomics: Maternal high-fat diet exposure in utero disrupts peripheral circadian gene expression in nonhuman primates. FASEB J 25: 714-726.

Suter MA, Sangi-Haghpeykar H, Showalter L, Shope C, Hu M, Brown K, Williams S, Harris RA, Grove KL, Lane RH, et al. 2012. Maternal high-fat diet modulates the fetal thyroid axis and thyroid gene expression in a nonhuman primate model. Mol Endocrinol 26: 2071-2080.

Szostak-Wegierek D. 2014. Intrauterine nutrition: Longterm consequences for vascular health. Int $J$ Womens Health 6: 647-656.

Tanda R, Salsberry PJ, Reagan PB, Fang MZ. 2012. The impact of prepregnancy obesity on children's cognitive test scores. Matern Child Health J 17: 222-229.

Tanne JH. 2012. Maternal obesity and diabetes are linked to children's autism and similar disorders. BMJ 344: e2768. 
Thakali KM, Saben J, Faske JB, Lindsey F, Gomez-Acevedo H, Lowery CL Jr, Badger TM, Andres A, Shankar K. 2014. Maternal pregravid obesity changes gene expression profiles toward greater inflammation and reduced insulin sensitivity in umbilical cord. Pediatr Res 76: 202-210.

Tozuka Y, Wada E, Wada K. 2009. Diet-induced obesity in female mice leads to peroxidized lipid accumulations and impairment of hippocampal neurogenesis during the early life of their offspring. FASEB J 23: 1920-1934.

Tozuka Y, Kumon M, Wada E, Onodera M, Mochizuki H, Wada K. 2010. Maternal obesity impairs hippocampal $\mathrm{BDNF}$ production and spatial learning performance in young mouse offspring. Neurochem Int 57: 235-247.

Tsai PJ, Davis J, Bryant-Greenwood G. 2015. Systemic and placental leptin and its receptors in pregnancies associated with obesity. Reprod Sci 22: 189-197.

Turnbaugh PJ, Gordon JI. 2009. The core gut microbiome, energy balance and obesity. J Physiol 587: 4153-4158.

Turnbaugh PJ, Ley RE, Mahowald MA, Magrini V, Mardis ER, Gordon JI. 2006. An obesity-associated gut microbiome with increased capacity for energy harvest. Nature 444: $1027-1031$

Turner CL, Mackay DM, Callaway JL, Docherty LE, Poole RL, Bullman H, Lever M, Castle BM, Kivuva EC, Turnpenny PD, et al. 2010. Methylation analysis of 79 patients with growth restriction reveals novel patterns of methylation change at imprinted loci. Eur J Hum Genet 18: 648655.

Van Lieshout RJ, Taylor VH, Boyle MH. 2011. Pre-pregnancy and pregnancy obesity and neurodevelopmental outcomes in offspring: A systematic review. Obes Rev 12: e548-e559.

van Straten EM, Bloks VW, Huijkman NC, Baller JF, van Meer H, Lutjohann D, Kuipers F, Plosch T. 2010. The liver $\mathrm{X}$-receptor gene promoter is hypermethylated in a mouse model of prenatal protein restriction. Am J Physiol Regul Integr Comp Physiol 298: R275-R282.

Vucetic Z, Reyes TM. 2010. Central dopaminergic circuitry controlling food intake and reward: Implications for the regulation of obesity. Wiley Interdiscip Rev Syst Biol Med 2: $577-593$.

Vucetic Z, Kimmel J, Totoki K, Hollenbeck E, Reyes TM. 2010. Maternal high-fat diet alters methylation and
Maternal Obesity and Fetal Programming

gene expression of dopamine and opioid-related genes. Endocrinology 151: 4756-4764.

Vuguin PM, Hartil K, Kruse M, Kaur H, Lin CL, Fiallo A Glenn AS, Patel A, Williams L, Seki Y, et al. 2013. Shared effects of genetic and intrauterine and perinatal environment on the development of metabolic syndrome. PLoS ONE 8: e63021.

Walker SP, Ugoni AM, Lim R, Lappas M. 2014. Inverse relationship between gestational weight gain and glucose uptake in human placenta from female foetuses. Pediatr Obes 9: e73-e76.

White CL, Pistell PJ, Purpera MN, Gupta S, Fernandez-Kim SO, Hise TL, Keller JN, Ingram DK, Morrison CD, BruceKeller AJ. 2009. Effects of high fat diet on Morris maze performance, oxidative stress, and inflammation in rats: Contributions of maternal diet. Neurobiol Dis 35: 3-13.

WHO. 2013. Obesity and overweight: Media centre.

Wienholds E, Plasterk RH. 2005. MicroRNA function in animal development. FEBS Lett 579: 5911-5922.

Williams L, Seki Y, Vuguin PM, Charron MJ. 2014. Animal models of in utero exposure to a high fat diet: A review. Biochim Biophys Acta 1842: 507-519.

Wu YW, Colford JM Jr. 2000. Chorioamnionitis as a risk factor for cerebral palsy: A meta-analysis. JAMA 284: $1417-1424$.

Yan X, Huang Y, Zhao JX, Rogers CJ, Zhu MJ, Ford SP, Nathanielsz PW, Du M. 2013. Maternal obesity downregulates microRNA let-7g expression, a possible mechanism for enhanced adipogenesis during ovine fetal skeletal muscle development. Int J Obes (Lond) 37: 568-575.

Zamore PD, Haley B. 2005. Ribo-gnome: The big world of small RNAs. Science 309: 1519-1524.

Zhang J, Zhang F, Didelot X, Bruce KD, Cagampang FR, Vatish M, Hanson M, Lehnert H, Ceriello A, Byrne CD. 2009. Maternal high fat diet during pregnancy and lactation alters hepatic expression of insulin like growth factor-2 and key microRNAs in the adult offspring. BMC Genom 10: 478.

Zhu MJ, Du M, Nathanielsz PW, Ford SP. 2010. Maternal obesity up-regulates inflammatory signaling pathways and enhances cytokine expression in the mid-gestation sheep placenta. Placenta 31: 387-391. 


\title{
$\&_{\mathrm{CSH}}^{\infty} \&$ Cold Spring Harbor

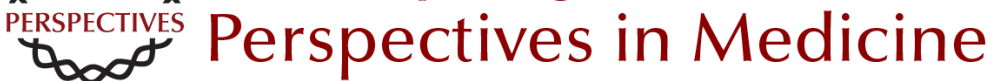

\section{Effects of Maternal Obesity on Fetal Programming: Molecular Approaches}

\author{
Caterina Neri and Andrea G. Edlow
}

Cold Spring Harb Perspect Med 2016; doi: 10.1101/cshperspect.a026591 originally published online September 3, 2015

\section{Subject Collection Molecular Approaches to Reproductive and Newborn Medicine}

Intergenerational Transfer of Epigenetic

Information in Sperm

Oliver J. Rando

\section{Effects of Maternal Obesity on Fetal Programming: Molecular Approaches Caterina Neri and Andrea G. Edlow}

The Neonatal Salivary Transcriptome Jill L. Maron

The Role of Hox Genes in Female Reproductive Tract Development, Adult Function, and Fertility Hongling Du and Hugh S. Taylor

\section{Molecular Cross-Talk at the Feto-Maternal Interface}

Gendie E. Lash

\section{Molecular Regulation of Parturition: A Myometrial Perspective \\ Nora E. Renthal, Koriand'r C. Williams, Alina P. Montalbano, et al.}

Genome-Wide Sequencing for Prenatal Detection of Fetal Single-Gene Disorders Ignatia B. Van den Veyver and Christine M. Eng

MicroRNA in Ovarian Biology and Disease Lynda K. McGinnis, Lacey J. Luense and Lane K. Christenson
A Molecular Perspective on Procedures and Outcomes with Assisted Reproductive Technologies Monica A. Mainigi, Carmen Sapienza, Samantha Butts, et al.

Whole-Exome Sequencing and Whole-Genome Sequencing in Critically III Neonates Suspected to Have Single-Gene Disorders

Laurie D. Smith, Laurel K. Willig and Stephen F. Kingsmore

Noninvasive Antenatal Determination of Fetal

Blood Group Using Next-Generation Sequencing Klaus Rieneck, Frederik Banch Clausen and Morten Hanefeld Dziegiel

Potential Uses and Inherent Challenges of Using Genome-Scale Sequencing to Augment Current Newborn Screening Jonathan S. Berg and Cynthia M. Powell

Molecular Regulation of Parturition: The Role of the Decidual Clock Errol R. Norwitz, Elizabeth A. Bonney, Victoria V. Snegovskikh, et al.

Molecular Mechanisms of Preeclampsia Tammy Hod, Ana Sofia Cerdeira and S. Ananth Karumanchi

Noninvasive Prenatal Screening for Genetic Diseases Using Massively Parallel Sequencing of Maternal Plasma DNA Lyn S. Chitty and Y. M. Dennis Lo

Confrontation, Consolidation, and Recognition: The Oocyte's Perspective on the Incoming Sperm David Miller

For additional articles in this collection, see http://perspectivesinmedicine.cshlp.org/cgi/collection/ 